\title{
INITIATING A NON-ANTHROPOCENTRIC JURISPRUDENCE: THE RULE OF LAW AND ANIMAL VULNERABILITY UNDER A PROPERTY PARADIGM
}

\author{
MANEESHA DECKHA*
}

This article discusses a recent Canadian entry to the accretion of legal texts which question, to various degrees, law's anthropocentrism: the dissenting judgment of the Alberta Court of Appeal in Reece v. Edmonton (City of). Written by Chief Justice Catherine Fraser, the 162paragraph dissent stands out in the Canadian landscape (and is impressive even in the international scene) given the existing Canadian law addressing animal issues that either regulate animals as objects and/or subordinate animal interests to human or corporate ones. This article argues that the dissent in Reece departs from the standard legal instrumentalist view of animals by providing a nonanthropocentric analysis of the animal interests at stake. The decision thus provides a new way of thinking about animals when compared to the existing Canadian jurisprudence. The dissent's departure from the traditional anthropocentric legal view of animals is seen in three main ways: (1) the level of importance it assigns to the animal interest legally at issue by connecting it to the rule of law; (2) the respect it affords to critiques of animals' current legal status (including the animal rights critique seeking to abolish the property status of animals and the default subordination of animal interests to human or corporate ones); and (3) the empathy and respect it gives to the individual animal at the heart of the legal dispute by recognizing her as a sentient and vulnerable being whose subjectivity matters. The cumulative effect is a judgment that not only provides the most sophisticated Canadian judicial analysis to date of the law's relationship to animals, but impugns the traditional anthropocentric paradigm through which the law minimally responds to (some) animal suffering.
Cet article porte sur la récente entrée canadienne dans l'accroissement des textes juridiques remettant plus ou moins en question l'anthropocentrisme du droit. Il s'agit du jugement dissident de la cour d'appel de l'Alberta dans Reece c. Edmonton (Ville d'). Écrit par la juge en chef Catherine Fraser, le jugement dissident de 162 paragraphes se distingue dans le paysage canadien (il est impressionnant même sur la scène internationale)compte tenu du fait qu'il existe au Canada, une loi régissant les questions animales qui considère les animaux comme des objets et (ou) qui subordonnent les intérêts des animaux aux intérêts des humains ou des sociétés. L'auteur de l'article fait remarquer que la dissidence dans Reece s'éloigne de l'opinion juridique traditionnelle d'instrumentaliste des animaux au moyen d'une analyse non anthropocentrique des intérêts des animaux en jeu. Cette décision donne ainsi une nouvelle manière de penser aux animaux dans le contexte de la jurisprudence canadienne. Le fait que le jugement s'éloigne du point de vue anthropocentrique juridique traditionnel des animaux est interprété de trois manières différentes : 1) le degré d'importance accordé aux intérêts juridiques des animaux en question en faisant le lien avec la règle du droit; 2) le respect accordé aux critiques de l'état juridique actuel des animaux (incluant les revendications de ceux qui désirent abolir le statut de propriété des animaux et la subordination par défaut des intérêts des animaux aux intérêts des humains et des sociétés); et 3) l'empathie et le respect accordés à l'animal en question qui se trouve au cœur de ce débat juridique en le reconnaissant comme un être vulnérable et doué de sensation, dont la subjectivité importe. L'effet cumulatif donne un jugement qui non seulement fournit l'analyse judiciaire canadienne la plus sophistiquée à ce jour de la relation entre le droit et les animaux, mais attaque le paradigme anthropocentrique traditionnel à partir duquel la loi réagit pour le moins à (certaines) souffrances animales.

\section{TABLE OF CONTENTS}

I. INTRODUCTION . . . . . . . . . . . . . . . . . . . . . 784

II. The Dominant Legal PARdigm: Animals As PROPERTy . . . . . . . . . 787

III. SOME SLIGHT DiSRUPTIONS TO TRADITIONAL LEGAL THINKING: COMPANION ANIMAL INITIATIVES . . . . . . . . . . . 790

Associate Professor, Faculty of Law, University of Victoria. The author is grateful to the Social Sciences and Humanities Research Council whose funds supported this article. The author would like to thank Michelle Stimac and Catherine George for their excellent research assistance. 


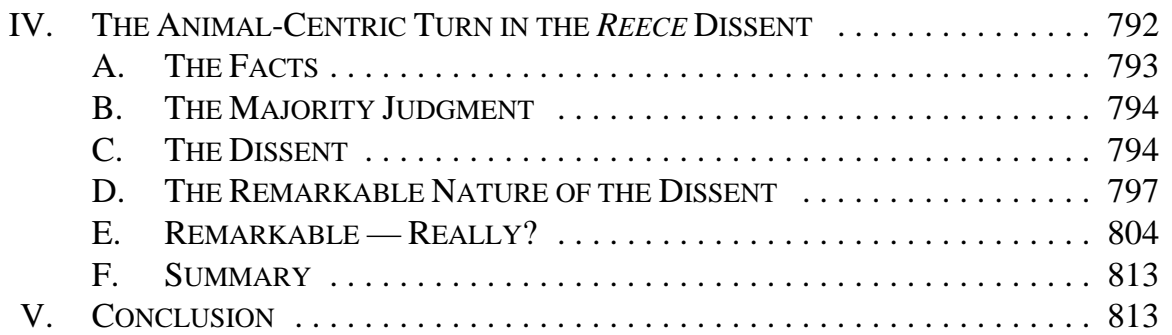

\section{INTRODUCTION}

Law is an anthropocentric terrain. Not only is law the product of human actors, it entrenches the interests of humans over virtually all others and centres the reasonable human person as a main legal subject. ${ }^{1}$ The one major area where law departs from its anthropocentric focus is in its recognition of corporate interests. Like humans, corporations are legal persons and the law has long recognized their rights. ${ }^{2}$ In terms of advertence to the interests of nonhumans then, it is corporations that feature prominently. Other nonhuman actors - trees, streams, and gardens, for example — are not so lucky. As non-persons, these entities do not count in law and only benefit indirectly, that is, when their interests align with those of legal persons. This is true even for nonhuman animals who are the living, breathing, sentient Others through which human identity is consolidated culturally and maintained legally. ${ }^{3}$

There are, however, moments of resistance to law's normative framework insofar as they call attention to the pattern by which law routinely favours human interests over (noncorporate) nonhumans. Though still rare and lacking in significant precedential impact, these instances contest law's anthropocentric values and effect. For example, some international interventions have sought to grant certain nonhuman animals the first generation rights of life, liberty, and freedom from torture. ${ }^{4}$ While not as bold in seeking rights and personhood

$1 \quad$ Mayo Moran, Rethinking the Reasonable Person: An Egalitarian Reconstruction of the Objective Standard (Oxford: Oxford University Press, 2003) at 1-3.

2 For an American overview of corporate rights see e.g. David H Gans \& Douglas T Kendall, "A Capitalist Joker: The Strange Origins, Disturbing Past, and Uncertain Future of Corporate Personhood in American Law” (2011) 44:3 J Marshall L Rev 643. For a Canadian perspective see e.g. Chris Tollefson, “Corporate Constitutional Rights and the Supreme Court of Canada” (1994) 19:1 Queen's LJ 309.

$3 \quad$ See e.g. Joan Dunayer, Animal Equality: Language and Liberation (Derwood, MD: Ryce, 2001) ch 3 ("[t]he greater the apparent psychological distance between nonhuman and human animals, the more secure humans' assumption of species superiority and uniqueness. This assumption provides a rationale for exploitation” ibid at 23); Paola Cavalieri, The Animal Question: Why Nonhuman Animals Deserve Human Rights, translated by Catherine Wollard (Oxford: Oxford University Press, 2001) ch 4 ("[a]ccording to the current moral paradigm, all human beings are equal and are entitled to the same fundamental moral protection. Animals, on the other hand, while counting for something, have an utterly inferior status.... Species membership determines inclusion in either of the two moral categories" ibid at 69-70).

$4 \quad$ For the sake of simplicity, I will use the term "animals" to refer to nonhuman animals. In using the term "animal" to refer to beings that are not human, the binary between human and not human is at best unchallenged and at worst strengthened. It is this very binary that I seek to disrupt. However, what is gained by this word choice, besides greater ease for the reader, is the acknowledgment that nonhumans are different; difference, rather than sameness, is thus valued. Erica Fudge, in the closing pages of her book entitled Animal explains: "It is hard to deny that 'the animal', the general singular with its definite article, wipes out all difference apart from the difference of the named from the namers.... By simultaneously using and laying bare the concept 'animal' as a cover-all for a disconcertingly wide range of relations, I hope to have underlined the discomfort, the variety and the limitations of those relations. 
for animals, and quite tepid when viewed through an animal non-exploitation worldview, other initiatives have nonetheless contested the traditional property classification for animals in several private law areas. ${ }^{5}$ Here, the relationships humans have with their companion animals are placing some pressure on law to catch up to these cultural affections relationships that the law still primarily disavows through its commodified rather than relational valuation of animals. ${ }^{6}$

This article discusses a recent Canadian entry to this accretion of legal texts questioning, in various degrees, law's anthropocentrism: the dissenting judgment of the Alberta Court of Appeal in Reece v. Edmonton (City of). ${ }^{7}$ Written by Chief Justice Catherine Fraser, the 162paragraph dissent stands out in the Canadian landscape (and is impressive even in the international scene) given the existing Canadian law addressing animal issues that either regulate animals as objects and/or subordinate animal interests to human or corporate ones. ${ }^{8}$ This article will argue that the dissent in Reece departs from the standard legal instrumentalist view of animals by providing a non-anthropocentric analysis of the animal interests at stake. The decision thus provides a new way of thinking about animals when compared to the existing Canadian jurisprudence. ${ }^{9}$

The dissent's departure from the traditional anthropocentric legal view of animals is seen in three main ways: (1) the level of importance it assigns to the animal interest legally at issue by connecting it to the rule of law; (2) the respect it affords to critiques of animals' current legal status (including the animal rights critique seeking to abolish the property status of animals and the default subordination of animal interests to human or corporate ones); and (3) the empathy and respect it affords to the individual animal at the heart of the legal dispute by recognizing her as a sentient and vulnerable being whose subjectivity matters. The cumulative effect is a judgment that not only provides the most sophisticated Canadian judicial analysis to date of the law's relationship to animals, but impugns the traditional anthropocentric paradigm through which the law minimally responds to (some) animal suffering and instantiates legal recognition of the subjectivity of sentient animals.

And from this, perhaps, it is not only the concept, but the lived relations that might come under scrutiny" (Erica Fudge, Animal (London: Reaktion Books Ltd, 2002) at 162-64). Fudge, among many others, draws from the works of Jacques Derrida, who guides a thorough contemplation of animal terminology and human/nonhuman relations more generally. See generally Jacques Derrida, "The Animal That Therefore I Am (More to Follow)” (2002) 28:2 Critical Inquiry 369 (translated by David Wills). See also Raymond Corbey, The Metaphysics of Apes: Negotiating the Animal-Human Boundary (Cambridge: Cambridge University Press, 2005) ("why respect beings that are similar in particular, while much of ethics is about respect for what is different?” ibid at 175).

See Part III below.

For a discussion of the commodification of companion animals see generally Kimberly K Smith, “A Pluralist-Expressivist Critique of the Pet Trade” (2009) 22:3 Journal of Agricultural \& Environmental Ethics 241.

2011 ABCA 238, 513 AR 199, leave to appeal to SCC refused, 34454 (26 April 2012) [Reece].

Federal legislation that facilitates the subordination and objectification of animals includes the Health of Animals Act, SC 1990, c 21; the Meat Inspection Act, RSC 1985, c 25 (1st Supp); the Fisheries Act, RSC 1985, c F-14; and the Species at Risk Act, SC 2002, c 29. Provincial legislation mirrors federal laws pertaining to the exploitation of animals, as can be seen in Ontario's Game and Fish Act, RSO 1990, c G-1 and British Columbia's Fur Farm Act, RSBC 1996, с 167. Anti-cruelty provisions, whether of provincial or federal provenance, and as I will discuss further below, facilitate the industries that are the subject matters of these acts (see Criminal Code, RSC 1985, c C-46, ss 444, 445, 445.1, 446; Prevention of Cruelty to Animals Act, RSBC 1996, с 372 [PCAA]).

$9 \quad$ Lesli Bisgould describes the Chief Justice's dissent as potentially "the most important development for animals in Canadian jurisprudence to date” (Lesli Bisgould, Animals and the Law (Toronto: Irwin Law, 2011) at 120). 
Before proceeding, it is helpful to clarify that while Chief Justice Fraser's dissent provides a non-anthropocentric account of the issues at stake, here defined as an analysis that challenges the species hierarchy that privileges human subjectivities and interests and discounts, disavows, or ignores animal ones, ${ }^{10}$ it does not rise to the level of a posthumanist judgment. Posthumanism is more than a normative orientation that challenges anthropocentrism and the species hierarchy inherent to it; it also eschews human-based metrics and methodologies for assessing who or what should count ethically to instead recognize nonhuman animal subjectivities on their own terms. ${ }^{11}$ As the analysis here reveals, the dissent's reasoning retains human markers for assessing subjectivity and resides within the traditional humanist legal framework. Similarly, the decision is not one that calls for the end of animal exploitation or their instrumental use. The intent here is not to present the dissent as an ideal decision for animals. Rather, the purpose is to argue that this decision goes considerably further than any Canadian animal judgment to date in departing from the law's standard instrumentalist view of animals. Despite its humanist underpinnings and its acceptance of a statutory and wider legal regime that classifies animals as property, the dissent is nonetheless striking compared to other judicial treatment of animal issues due to the extent to which it facilitates a critique of the conventional anthropocentric framework the law applies to animals.

To illuminate the remarkability of this minority decision, the first part of this article provides a brief overview of the traditional and dominant legal status assigned to animals: property. Part II explains how the impact of anti-cruelty statutes — the often exclusive legal vehicle used in common law jurisdictions to target animal suffering — is severely hampered

The notion of anthropocentrism has been recognized for centuries in Western philosophy, and has been variously praised and criticised by academics. Though definitions vary, the essential element of the concept is the privileging of the "human" over the "animal." For example, Gary Steiner describes anthropocentism as the conclusion that "human beings ... enjoy priority over animals in considerations of moral worth”: Gary Steiner, Anthropocentrism and its Discontents: The Moral Status of Animals in the History of Western Philosophy (Pittsburg: University of Pittsburg Press, 2005) at 2. Steiner's book offers a contextualization of the development of anthropocentrism in dominant Western thought. For a slightly different definition see e.g. Onora O’Neill, “Environmental Values, Anthropocentrism and Speciesism” (1997) 6:2 Environmental Values 127 at 128.

11 Cary Wolfe, “Human, All Too Human: ‘Animal Studies’ and the Humanities” (2009) 124 Proceedings of the Modern Language Association 564 at 572. Posthumanism, although difficult to define, can be said to challenge "the ontological and ethical divide between humans and non-humans": Cary Wolfe, "Flesh and Finitude: Thinking Animals in (Post)Humanist Philosophy” (2008) 37:3 SubStance 8 at 8. I am grateful to an anonymous reviewer for directing me to this citation. It is important to note that some scholars also conflate the two concepts, that is, seeing anthropocentrism not just where humans are favoured over nonhumans, but where human ways of knowing and experiencing the world are prioritized. See Kevin DeLapp, “The View from Somewhere: Anthropocentrism in Metaethics” in Rob Boddice, ed, Anthropocentrism: Humans, Animals, Environments (Leiden: Brill, 2011) 37 at 38; Rob Boddice, "Introduction: The End of Anthropocentrism" in Boddice, ibid 1 at 1 . For further discussion of posthumanism see the work of Cary Wolfe, who has developed posthumanist analysis through animal studies: Cary Wolfe, "Learning from Temple Grandin, or, Animal Studies, Disability Studies, and Who Comes After the Subject” (2008) 64 New Formations 110; Cary Wolfe, Animal Rites: American Culture, The Discourse of Species, and Posthumanist Theory (Chicago: University of Chicago Press, 2003) [Wolfe, Animal Rites]; Cary Wolfe, What is Posthumanism? (Minneapolis: University of Minnesota Press, 2010). Also formative to the posthumanist movement is the work of Donna Haraway, which problematizes both the animal and the cyborg as subjects of moral analysis. See e.g. Donna Haraway, Primate Visions: Gender, Race, and Nature in the World of Modern Science (New York: Routledge, 1989); Donna J Haraway, When Species Meet (Minneapolis: University of Minnesota Press, 2008) [Haraway, When Species Meet]; Donna Haraway, “A Manifesto for Cyborgs: Science, Technology, and Socialist Feminism in the 1980s” (1985) 80 Socialist Review 65; Donna Haraway, The Companion Species Manifesto: Dogs, People, and Significant Otherness (Chicago: Prickly Paradigm Press, 2003). For an overview of the diverse interpretations and applications of posthumanism see generally Neil Badmington, ed, Posthumanism (New York: Palgrave, 2000); Judith Halberstam \& Ira Livingston, eds, Posthuman Bodies (Bloomington: Indiana University Press, 1995). 
by the traditional and ongoing legal status of animals as property. Part III then outlines the (few) legal developments that have occurred for (companion) animals in Canada and the United States in the realm of private law areas related to family life that attempt to circumvent the effects of their propertied legal status. The discussion explains the partial ways in which these developments contest companion animals' property status and explains how the anthropocentric orientation of these developments limits their scope. The remarkable nature of the dissent in Reece, discussed in Part IV, comes clearly into focus against this backdrop as we see how the dissent in this appellate level judgment brings a more sophisticated and non-anthropocentric consciousness of who animals are and what they are worth to Canadian jurisprudence.

\section{The Dominant Legal Paradigm: ANimals as Property}

Nonhuman animals, both domestic and wild, are classified as property in the Canadian legal system. ${ }^{12}$ The legal frameworks that enforce the property status of animals can be roughly conceptualized as two-fold: (1) domestic animals are the property of their owners, who might be an individual, a family, or a corporation; and (2) wild animals, though common property and thus not said to be owned by anyone, are subject to the property granting regime of government. ${ }^{13}$ Being classified as "wild" does not change the commodifiable status of animals as governments maintain the authority to attribute ownership in animals to persons through licensing and hunting regulation. ${ }^{14}$ Though each framework manifests slightly differently, they are both based on the normative assumption that humans are subjects, capable of owning property, and nonhumans (other than corporate bodies) are objects to which property rights attach.

As objects, embodying what Steven Wise calls "legal thinghood," rights and their interests are legally irrelevant; socially, nonhuman animals are presented as inferior to human animals and the law reinforces and even amplifies this narrative through a sharp species divide. ${ }^{16}$ Thus, as legal subjects who occupy the centre around which the law revolves, ${ }^{17}$ it is the rights of the human and corporate owners that are protected and privileged when interests conflict. Gary Francione, who argues that the treatment of animals will not change until their property status is displaced, pithily summarizes the current

Bruce Ziff, Principles of Property Law, 5th ed (Toronto: Carswell, 2010) at 134.

The distinction between wild and domestic is largely self-fulfilling. In the few instances where such a definition is articulated, it is based on the reasoning that those animals classified as domestic are those which are tamed and owned by humans. See e.g. $R v$ Morelli, 2002 SKQB 294, 222 Sask R 66 at para 21 [Morelli]: "[I]n a broad sense, the term would include any tame animal, even tame farm animals especially if they were kept as pets."

14 See e.g. Wildlife Act, RSBC 1996, c 488; Wildlife Act, RSA 2000, c W-10, s 7(1); The Wildlife Act, 1998, SS 1998, c W-13.12, s 23; Maynes v British Columbia, 2009 BCCA 499, 278 BCAC 113.

15 Steven M Wise, “The Legal Thinghood of Nonhuman Animals” (1996) 23:3 BC Envtl Aff L Rev 471 ("[l]egal thinghood describes an entity with no capacity for legal rights. Its interests, if they exist, are not required to be respected. Instead, the entity is treated as property about which legal persons have legal rights and duties" ibid at 472).

16 See e.g. Lyne Létourneau, "Toward Animal Liberation? The New Anti-Cruelty Provisions in Canada and their Impact on the Status of Animals" (2003) 40:4 Alta L Rev 1041 at 1048; Taimie L Bryant, "Sacrificing the Sacrifice of Animals: Legal Personhood for Animals, The Status of Animals as Property, and the Presumed Primacy of Humans” (2008) 39:2 Rutgers LJ 247 (“[t]he property status of animals is integrally connected to the presumed moral superiority and entitlement of humans" ibid at 328). Wendy A Adams, "Human Subjects and Animal Objects: Animals as "Other” in Law" (2009) 3:1 J Animal L \& Ethics 29 at 32. 
situation: "To the extent that the law recognizes that animals have interests, those interests are recognized only to the extent that they facilitate the use of the animal as property." ${ }^{18}$ Even theorists who disagree with the "abolitionist" position that Francione advocates (that the property status of animals must be abolished for meaningful change to occur) recognize that in a situation of conflict the overwhelming majority of human interests will always prevail over animal ones. ${ }^{19}$

Given the dominance of the property framework for animals, government action on the protection of animals takes the form of regulation rather than abolition of exploitative practices. The measures are "welfarist" in nature in that the government is implicitly accepting the property status and corresponding instrumental use of the animal, and simply limiting the degree of suffering that is legally acceptable. ${ }^{20}$ These measures, where they do exist, can affect and improve the welfare of individual animals, but they do little to promote nonhumans as legal subjects deserving of personhood and protection from human and corporate exploitation. Instead, welfarist measures, primarily housed under anti-cruelty statutes, are mostly entrenched in the paradigm of "unnecessary" suffering where the necessity of suffering is implicitly correlated with existing industry standards and economic rationales. ${ }^{21}$ With this as the standard, almost every socially acceptable practice in relation to animals is regarded as "necessary."22

As Francione has demonstrated in his review of anti-cruelty statutes across the US, animals typically matter as an afterthought only after human interests, no matter how trivial, are satisfactorily addressed. Under these statutes, acts are judged to constitute "cruelty" typically only where that human interest is determined to fall outside dominant cultural or industry/economic norms. ${ }^{23}$ In her review of Canadian cases arising from the anti-cruelty provisions of the Criminal Code, Lesli Bisgould confirms that the treatment of animals used in institutional contexts (practices related to farming, research, entertainment, etc.) is seldom subject to anti-cruelty scrutiny. She notes that "[e]xceptions are rare, and generally arise where the harm is not related directly to the actual practice, the animal resource is being wasted, and the suffering is gratuitous, such as when a herd of animals is starved."24

Gary L Francione, “Animal Rights and Animal Welfare” (1996) 48:2 Rutgers L Rev 397 at 445.

Welarist theorists, as well as abolitionists, are cognisant of the reality that human interests are currently given much more weight than those of animals. For example, David Favre writes that "[s]ociety, through the legislature, has made a judgment that human interests in hunting and trapping wildlife deserve more weight than the pain and suffering that these acts cause to wildlife": David Favre, "Wildlife Jurisprudence” (2010) 25:2 J Envt L \& Litig 459 at 492.

20 See also Bisgould, supra note 9 at $8,11$.

$21 \quad$ Ibid at 58-60, 71. See e.g. Gary L Francione, “Animals, Property and Legal Welfarism: 'Unnecessary' Suffering and the 'Humane' Treatment of Animals” (1994) 46:2 Rutgers L Rev 721 [Francione, "Welfarism”]; $R$ v Ménard, 43 CCC (2d) 458 [Ménard]. In Ménard, Justice Lamer (as he then was) found that "[t]he animal is subordinate to nature and to man. It will often be in the interests of man to kill and mutilate wild or domestic animals, to subjugate them and, to this end, to tame them with all the painful consequences this may entail": ibid at 464. Justice Lamer's ratio, that "the expression 'without necessity' must be interpreted taking into account the privileged position which man occupies in nature": ibid at 465 was followed in the following judgments: $R v$ McRae, [2002] OJ no 4987 (QL); $R v$ Mousseau, 2011 QCCQ 11101, [2011] JQ no 13401 (QL); Rv Cunningham, 2011 BCPC 358, 102 WCB (2d) 362 [Cunningham].

22 See Francione, "Welfarism," supra note 21.

23 Ibid at 766 ("[o]nce an activity is regarded as legitimate, animal killing or suffering that occurs as part of the activity is acceptable.... The only activities that remain to be prohibited by such statutes are those where there is no socially recognized benefit that can be traced to the animal killing or suffering”).

24 Bisgould, supra note 9 at 72 . For a survey of the application of criminal anti-cruelty laws to industrial animal exploitation, see ibid at 71-75. The federal anti-cruelty provisions are housed in sections 445.1447.1 of the Criminal Code, supra note 8. 
To illustrate their point about the highly selective nature of which animal-based practices are targeted, consider the practices of animal fighting and baiting. Given the current disapproval of these activities in Canada and the US by cultural majorities, such practices appear as clear anti-cruelty violations in many such statutes, commanding their own provision or easily interpreted as falling under the catchall "unnecessary suffering” provision in anti-cruelty statutes. ${ }^{25}$ Yet, factory farming or vivisection, which enjoy widespread public acceptance, do not qualify as "cruelty" despite the fact that the level of suffering of animals from the routine practices in these industries may be equivalent to, or exceed, the suffering in animal fighting and baiting. ${ }^{26}$ Also noteworthy is that animal fighting and baiting and other blood sports are spectacles that the law has only relatively recently labeled as "unnecessary" and thus "cruel”, ${ }^{27}$ such practices were once socially embraced and legal. ${ }^{28}$ These cultural and temporal dimensions of the legal meaning of "cruelty to animals" reflect the anthropocentric (and, often, class- and race-based) cultural attitudes about what is "necessary" that heavily shape the law. ${ }^{29}$ It is a legal doctrine that defers to industry standards that value animals economically. Indeed, many anti-cruelty statutes explicitly shield industry practices from their purview. ${ }^{30}$

In Canada, animal fighting and baiting are prohibited under section 445.1(1)(b) of the Criminal Code, ibid, and an entire section is devoted to the prohibition of cockfighting under section 447. In the US, while all states have laws against the facilitation of animal fighting, a federal law was enacted in 2007 (see Animal Fighting Prohibition Enforcement Act of 2007 Pub L No 110-22, 121 Stat 88).

For an overview of the industrial opposition to anti-cruelty legislation reform, see Bisgould, supra note 9 at $92-94$.

27 In the US, most states began prohibiting dog fighting in the 1860s, but not all states had a law in effect until 1976: Nancy R Hoffman \& Robin C McGinnis, "2007-2008 Legislative Review” (2008) 15:2 Animal L 265 at 276. Cock-fighting, on the other hand, only became illegal in every state in 2008 (ibid at 297). In Canada, criminal prohibitions against animal fighting can be traced back to at least 1835 (Bisgould, ibid at 62). In the same text, Bisgould provides examples from primary sources of the class dimensions explicit in the prohibition of animal fighting (ibid).

28 Kathryn Shevelow, For the Love of Animals: The Rise of the Animal Protection Movement (New York: Henry Holt and Company, 2008) at 7-8, 39-45.

29 See e.g. Richard A Posner, “Animal Rights: Legal, Philosophical, and Pragmatic Perspectives” in Cass R Sunstein \& Martha C Nussbaum, eds, Animal Rights: Current Debates and New Directions (Oxford: Oxford University Press, 2004) 51 at 66-74; Cavalieri, supra note 3 at 69-87; David DeGrazia, "On the Question of Personhood beyond Homo sapiens" in Peter Singer, ed, In Defense of Animals: The Second Wave (Malden, MA: Blackwell, 2006) 40 at 49-51; Wolfe, Animal Rites, supra note 11 at 2-9; Tom Regan, The Case for Animal Rights (Berkeley: University of California Press, 1983) at 226-28. See also Bisgould, supra note 9 at 75-81 where the "seriousness" of crimes against animals is shown to be a subjective notion, affected by social norms of the day. For a discussion of the class and racial motivations of these laws see Grace Moore, "Beastly Criminals and Criminal Beasts: Stray Women and Stray Dogs in Oliver Twist" in Deborah Denenholz Morse and Martin A Danahay, eds, Victorian Animal Dreams: Representations of Animals in Victorian Literature and Culture (Burlington, VT: Ashgate, 2007) 201.

30 Bisgould, ibid at 107-109. For example, in British Columbia, section 24.02 of the PCAA, supra note 8, addressing defences, states that "[a] person must not be convicted of an offence under this Act in relation to an animal in distress if ... the distress results from an activity that is carried out in accordance with reasonable and generally accepted practices of animal management.” Other provinces include similar exemptions. In Ontario, the Ontario Society for the Prevention of Cruelty to Animals Act, RSO 1990, c O.36, s 11.1(1) outlines the general obligation towards animals as being that "[e]very person who owns or has custody or care of an animal shall comply with the prescribed standards of care with respect to every animal that the person owns or has custody or care of." However, this section "does not apply in respect of ... an activity carried on in accordance with reasonable and generally accepted practices of agricultural animal care, management or husbandry”: ibid, s 11.1(2)(a). In Manitoba, The Animal Care Act, SM 1996, c 69, CCSM c A84, includes specifications on the duties of animal owners, such as the provision of adequate food, water, and shelter. However, exempted from these duties are all persons who treat an animal "in a manner ... consistent with generally accepted practices or procedures for such activity": ibid, s 2(2). The statute lists accepted activities, which include "(a) agricultural uses of animals; ... (d) animal slaughter; ... [and] (k) research and teaching involving animals": ibid, s 4(1). 
Where Canadian and, in particular, American law has shown more of a willingness to value animals as relational beings rather than just economic units is in private law areas inflected with family and relationship dynamics. The next part describes these developments to reveal how some legal texts in these areas imagine animals as more than economic entities yet still exhibit an anthropocentric orientation. Reviewing these recent developments and their limits helps elucidate the significance of the Reece dissent in the rest of the article.

\section{SOME SLIGHT DiSRUPTIONS TO TRADITIONAL LEGAL THINKING: COMPANION ANIMAL INITIATIVES}

Despite the saturation within the common law of a property status for animals, some exceptions to this traditional position are starting to emerge. These instances have so far been rare and partial in terms of how much they destabilize the property framework and the scope of animals to which they are meant to apply. ${ }^{31}$ In Canada, these developments have originated in the private law arena of tort law and overwhelmingly seek to protect domestic animals who occupy the role of companion and/or family member. For example, in tort cases concerning claims about the loss of, or harm to, a companion animal, some courts have awarded damages outside of the traditional "fair-market value" calculation. ${ }^{32}$ Other considerations, such as the guardian's emotional attachment to the animal or veterinary costs, have been recognized in the award ordered. ${ }^{33}$ These cases in Canada follow developments in the US where some courts and legislatures have developed mechanisms for acknowledging companion animals as more than ordinary property. ${ }^{34}$ Although the tort developments are clearly anthropocentric in that they address the loss experienced by the human owner and not the suffering experienced by the companion animal, ${ }^{35}$ other private law areas have witnessed more companion animal-centred approaches.

In family law cases in the US, some courts have applied the "best interest” test, normally applied to human children and not animal objects, in deciding with whom a companion animal should reside ${ }^{36}$ and whether one spouse owes the other "petimony" ${ }^{37}$ when the spouses separate. ${ }^{38}$ American legislatures have also provided tools for humans to incorporate companion animals into their estate plans as beneficiaries rather than property. Recognizing the desire by many to ensure the care of their companion animal should they themselves no longer be able to do so, 45 states have enacted statutes that allow for "pet trusts." 39

Other countries have given more attention to animals' interests, but even these initiatives are affected by welfarist inclinations despite the seemingly rights-based stature. See Part IV.E below.

32 Maneesha Deckha, "Property on the Borderline: A Comparative Analysis of the Legal Status of Animals in Canada and the United States” (2012) 20:2 Cardozo J Int’l \& Comp L 313 at 323. 33 For a discussion on these instruments of quantification see Kelly Wilson, "Catching the Unique Rabbit: 167. Wilson explores the limitations of damages for emotional duress in companion animal cases.

34 See generally Deckha, supra note 32. See also Bisgould, supra note 9 at $140-41$ where the author discusses the potential of the "intrinsic value" mechanism for quantifying damages.

Deckha, ibid at 327; Bisgould, ibid at 138.

Deckha, ibid at 333 .

Ibid at 344.

For a more extensive overview of the recent involvement of animals in family law decisions see Bisgould, supra note 9 at 154-60.

Deckha, supra note 32 at 348. 
In addition, 18 American municipalities and one state have responded favourably to campaigns to change terminology in municipal legislation concerning the human's relationship to their companion animals from "owner” to "guardian." 40 This symbolic change is meant to reinforce the non-property relation that many humans have with their companion animals and to promote consciousness and decision-making about companion animals that further the animal's interests as a cared for relation instead of the human's interests as property owner. ${ }^{41}$ Though this change does not alter animals' legal status as property, it represents animals in a non-commodified manner and supports the position that the relationship humans have with these family members should be legally conceptualized in this manner. ${ }^{42}$ American courts and legislatures are thus beginning to acknowledge the social status many companion animals enjoy as members of their human families. These developments implicitly cast animals as relational creatures and thus, however indirectly or ineffectually, question their traditional and dominant property and objectified categorization.

Canadian courts and legislatures have not proven as eager as their American counterparts to modify how property law principles are applied to animals. In family law cases, no Canadian judgment has definitively applied the "best interest" standard in deciding with whom an animal should live after separation of the human spouses; ${ }^{43}$ in fact, the courts have used cases involving "custody" disputes of animals to re-affirm the property status of these beings. ${ }^{44}$ In the area of estate planning, where the US has offered guardians the comfort of legislated pet estates, no similar federal or provincial statute exists in Canada. Likewise, in the movement to change the vocabulary of official documents from "owner" to "guardian," only one Canadian municipality has participated. ${ }^{45}$ It seems that, although Canadian tort law has generated some scope for a non-economic view of nonhumans that adds a relational valuation of animals that the federal and provincial anti-cruelty legislation do not, the courts and legislatures are reluctant to change the law as it is applied to companion animals in other areas. A fidelity to precedent and the property framework continue to prevail.

But even the American developments in this area cannot be read as radical or even nonanthropocentric. As noted above, the non-market valuation of animals that has occurred in tort cases responds to the human owner's sentiment toward that animal. Even the emergent "best interest" development in family law may be said to rely on a respect for the human owner's feelings toward the animals - sufficient enough to sue for custody or possession - rather than a respect for the animal qua animal. The same critique could also be applied to the trust developments in estate law enabling animals to stand as beneficiaries: the impetus and rationale for these developments is to respect human owners' needs for peace of mind due to their affective responses to their animals. Further, although these cases offer some

Ibid at 358, 362.

Ibid at 358-59; Susan J Hankin, "Making Decisions about Our Animals’ Health Care: Does it Matter Whether We Are Owners or Guardians?” (2009) 2 Stan J Animal L \& Pol'y 1. Hankin questions the role of "guardianship" terminology in health care decision-making (ibid at 5-8).

42 Deckha, ibid at 360.

43 Alain Roy has discussed how close the Quebec courts have come to applying the "best interest" test to companion animals. He cites decisions where the court stated that the sharing of a companion animal was the only acceptable decision, and where the parties were ordered to work together to sort out a suitable arrangement for the animal. Roy also points out that the French courts have indeed applied this test usually reserved for children to companion animals, an indication that Quebec courts may soon be doing the same. Alain Roy, “Papa, maman, bébé et ... Fido!” (2003) 82:3 Can Bar Rev 791 at 797-98. Deckha, supra note 32 at 338.

Ibid at 362 . 
resistance to the property status of animals, it is the companion identity of the animals at issue that motivates them. ${ }^{46}$ As such, animals who do not reside in such close relational and physical proximity to humans do not receive the benefit of these developments. ${ }^{47}$ Tellingly, despite the weak nature of the contestation of property status discussed here, these developments surrounding companion animals have still not attached to animals exploited for food, experimentation, entertainment, etc. In these industrial contexts involving intense animal exploitation, as Francione has argued, any animal welfare laws that may apply merely facilitate, streamline, and legitimate exploitation rather than genuinely attend to animal interests. $^{48}$

In contrast to the typical interpretation and application of welfarist statutes, the dissent in Reece insists on legal protection for a non-companion animal as well as a nonproperty/economic valuation that does not subordinate the animal's interest to human or corporate ones. It also emphasizes the vulnerability of animals, questions anthropocentric values, and legitimates animal suffering as a serious issue that engages the rule of law. In doing so, the dissent departs from the standard instrumentalist approach to animals in the law. To be clear, I am not suggesting that Chief Justice Fraser's dissent is an abolitionist judgment or even one that considers animals as equals along an animal citizenship, sovereignty, or other model. ${ }^{49}$ There are indeed serious limits to her analysis from an animalcentric perspective that I do not wish to gloss over or downplay. Yet, it would be a mistake to conflate Chief Justice Fraser's dissent with the standard judicial engagement with welfarist statutes or equate it to the minor property-contesting developments in private law regarding companion animals canvassed above. Her approach is significantly divergent from both to merit close attention. Indeed, Chief Justice Fraser's dissent charts new legal ground in Canada (as much as an appellate level dissent can) and, in doing so, affords an individual animal an unprecedented presence as a legal subject in a Canadian judgment.

\section{The ANIMAL-CENTRIC TURN IN THE REECE DiSSENT}

Having described the strict anthropocentric framework that encapsulates law, including anti-cruelty legislation, the purpose in this part is to demonstrate how the dissenting judgment in Reece initiates a turn against this jurisprudence in Canadian law. The first section sets out the facts of the case. This is followed by a description of the majority ruling. The third section then outlines the trajectory of Chief Justice Fraser's multi-part dissent, noting the salient points of her reasoning in each. With this background in place, the rest of this part explains how the dissent diverges from the standard legal instrumentalist view of

46

27 at 55

This is not to suggest that this relationship is a simple one of only love and affection. The complexity of the human-companion animal relationship is captured by Haraway when she writes that it is between "a motley array of lively beings, in which commerce and consciousness, evolution and bioengineering, and ethics and utilities are all in play": Haraway, When Species Meet, supra note 11 at 46. It may be aptly observed that in this way human-animal companion relationships share many features with humanhuman companion relationships.

48 Gary L Francione, "Reflections on Animals, Property, and the Law and Rain Without Thunder" (2007) 70:1 Law \& Contemp Probs 9 at 12-13. See also Darian M Ibrahim, "A Return to Descartes: Property, Profit, and the Ownership of Animals" (2007) 70:1 Law \& Contemp Probs 89. I am grateful to an anonymous reviewer for directing me to this citation.

49 For a citizenship and sovereignty-based account of animal justice see Sue Donaldson \& Will Kymlicka, Zoopolis: A Political Theory of Animal Rights (Oxford: Oxford University Press, 2011). 
animals, rendering animal subjectivity visible in Canadian law in a manner previously unseen and legitimating non-anthropocentric thinking about animals in the law.

\section{A. THE FACTS}

The case of Reece involved an attempt to improve living conditions for Lucy, a 36 year old Asian elephant resident at Edmonton's Valley Zoo. Since arriving at the zoo in 1977, Lucy had developed a long list of chronic health complaints, including arthritis, obesity, respiratory illness, foot infections, pressure sores, and dental disease. ${ }^{50}$ Additionally, by 2011, she had spent 16 of her 34 years at the zoo without elephant companionship. ${ }^{51}$ As female elephants are known to be very social, ${ }^{52}$ Lucy's solo status and numerous health issues attracted widespread outcry. ${ }^{53}$ When public pressure and a complaint to the city's Humane Society failed to prompt any changes, a group of animal advocates (the Appellants) applied to the courts for a declaration that, as the licenced operator of the zoo, the City of Edmonton (the City) had breached Alberta’s Animal Protection Act. ${ }^{54}$

The Act holds that "[n]o person shall cause or permit an animal ... to be in distress," with an animal in distress defined as, among other things, "deprived of adequate shelter ... space ... or reasonable protection from injurious heat or cold," and "injured, sick, in pain or suffering." 55 Veterinarians and biologists who reviewed zoo records concluded that Lucy's diminished health was the result of her environment, particularly her "severely confined

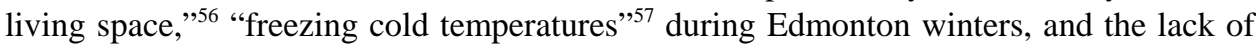
available companionship. ${ }^{58}$ The City, although willing to admit that Lucy suffered from health issues, rejected the allegation that her living conditions violated the Act. ${ }^{59}$ They applied to have the claim struck, on the grounds that the Appellants lacked standing and the application constituted an abuse of process. ${ }^{60}$ The lower Court agreed and dismissed the application. ${ }^{61}$

Reece, supra note 7 at paras 105, 107, 110.

Ibid at paras 39, 105. The zoo housed a female African elephant from 1989-2007.

Ibid at para 39.

Dean Bennett, “Bob Barker blasts Edmonton zoo for isolating elephant,” The Globe and Mail (23 February 2009), online: The Globe and Mail <http://www.theglobeandmail.com/news/national/bobbarker-blasts-edmonton-zoo-for-isolating-elephant/article/1149401>; Gordon Kent, "Alberta elephant gets lift from star writers; Ondaatje, Atwood want Lucy moved,” Calgary Herald (23 May 2009) D1. RSA 2000, c A-41 [the Act]. See Reece, supra note 7 at paras 4-5.

Animal Protection Act, ibid, ss 2(1), 1(2)(a)-(c).

Reece, supra note 7 at para 111. As Dr William Keith Lindsay notes, small living quarters mean "Lucy simply is unable to engage in her species-typical behaviour of extensive walking”: ibid at para 112.

Ibid at para 109. For further examples of the issues noted with Lucy’s living conditions see ibid at paras 103-25.

Ibid at para 123. The dissent characterizes the companionship issue as "Lucy’s having been kept in solitary isolation — some might use the words solitary confinement”: ibid at para 106.

Ibid at para 3.

Ibid at para 8. The City also alleged that the applicants should have used a statement of claim, rather than an originating notice (ibid at para 45). However, as a switch to a statement of claim is possible under court rules (ibid at paras 46, 48), I do not discuss this issue any further here.

See Reece v Edmonton (City of), 2010 ABQB 538, 498 AR 43. 


\section{B. THE MAJORITY JUdGMENT}

On appeal, the majority affirmed, holding that the application was indeed an abuse of process. ${ }^{62}$ Written by Justice Slatter and concurred in by Justice Costigan, the opinion declines to engage with the underlying animal questions and instead focuses on the internal workings of Canadian law. The majority refrains from discussing animal rights or reforms to animal welfare law on the basis that such issues go beyond the scope of the bare legal question. ${ }^{63}$ As a result, the decision turns on a procedural issue, specifically that a private attempt to "enforce or engage punitive penal statutes" is both an abuse of process and determinative of the standing issue. ${ }^{64}$ While recognizing that, in certain situations, a private litigant may request a remedy for a breach of public law, the majority holds that such an action should be denied where the remedy was "sought as a substitute for obtaining a ruling in a criminal case." 65 They further note that precedent does not support the extension of standing for an action requesting a declaration of penal statutory breach. ${ }^{66}$ Reasoning that such a declaration would diminish procedural protections and weaken the authority of public bodies, the majority determines that an appropriate remedy should not involve the courts. The judges write: "It is not appropriate to expect the courts to take over the animal husbandry of the animals at the City zoo through the ability to issue declarations on points of law."67 This decision is not surprising; it echoes the animal-silencing approach taken in other cases where animal advocates have challenged the actions of those with legal control over animals. ${ }^{68}$

\section{THE DISSENT}

The dissent in Reece, on the other hand, represents a dramatic shift away from this conventional attitude toward animal legal issues. The opinion is noteworthy for providing the first significant Canadian judicial consideration of an animal's right to a legal voice and the relationship of this right to the proper workings of our legal institutions. ${ }^{69}$ The dissent, unlike the majority, integrates the issue of the limits on judicial oversight into a larger question about the ties between animal welfare and the role of courts. The Chief Justice notes at the outset:

[T]his appeal raises important issues fundamental to the effective protection of animals in this province. Under what circumstances can citizens or advocacy groups be granted public interest standing to seek a declaratory judgment that the government itself has failed to comply with animal welfare laws? ... [This is]

Reece, supra note 7 at para 36. Bisgould describes the majority as employing a "broad interpretation" of the abuse of process doctrine (Bisgould, supra note 9 at 119).

Reece, ibid at paras 1-3, 12.

Ibid at para 20.

Ibid at para 22, Kourtessis $v$ Canada (Minister of National Revenue), [1993] 2 SCR 53.

Reece, ibid at para 24.

Ibid at para 35.

See e.g. Cassells v University of Victoria, 2010 BCSC 1213, 323 DLR (4th) 180, cited in Reece, ibid at para 27; Greenpeace Foundation of British Columbia $v$ British Columbia (Minister of the Environment), 122 DLR (3d) 179 (SC); Teja's Animal Refuge v Quebec (AG), 2009 QCCA 2310, 100 Admin LR (4th) 292. See also Bisgould, supra note 9 at 120. Bisgould is concerned that this decision might limit the potential enforceability of the Act.

Reece, ibid at para 90: "Animals, including Lucy, cannot commence lawsuits on their own to protect themselves. They must rely on humans to give voice to the truly voiceless.” See also ibid at para 166. 
linked to a crucial issue in a constitutional democracy. Is the government, and that includes the City as an arm of the state, immunized from judicial scrutiny of alleged unlawful acts? ${ }^{70}$

To answer this question, the opinion begins by situating the application in its wider legal context. Noting that "novel” issues should not be considered "in a vacuum," "71 Chief Justice Fraser goes on to review the history of animal law, describing a progression from an "era in which humans had the right to do with animals as they saw fit” to a present-day legal regime that, although it promotes human interests at the expense of animal welfare, does provide "some protection" for animals. ${ }^{72}$ In Alberta, she notes, those protections include the Act, the Wildlife Act, and the Government of Alberta Standards for Zoos in Alberta. ${ }^{73}$ The dissent then reviews criticisms of the animal welfare regime (that is, statutory protections weakened by equivocal wording, poor enforcement, and human interests trumping animal interests, and animal advocacy being hindered by procedural limitations) and considers a number of proposed solutions. ${ }^{74}$ The key for any reform, Chief Justice Fraser suggests, turns back to the central issue in the case: "If animals are to be protected in any meaningful way, they, or their advocates, must be accorded some form of legal standing at law."75

The dissent draws a twofold conclusion from these contextual concerns. First, the vulnerability of animals as a group and the limitations of the animal welfare regime suggest that "courts should not diminish the full import of animal protection laws by creating unnecessary barriers to those seeking to ensure compliance with them," but should rather take a "generous, not impoverished"76 approach to interpreting animal legislation and recognizing related claims. Second, once government has protected animals by law, the rule of law is engaged and the courts must work to see that those laws are respected and upheld, including by the government itself. ${ }^{77}$ "[A]nimal welfare legislation is not simply for show, to assuage our collective conscience, promising much but delivering little,"78 Chief Justice Fraser writes, asking further, "should there not be some effective means of vindication of such laws as exist?"79 Taken together, these considerations emphasize the importance of allowing a full hearing for the issues raised by the application. ${ }^{80}$

The opinion then turns to the errors with the Chambers Judge's decision. Chief Justice Fraser identifies three errors of law made by the lower court (and, by extension, the majority). The first, which she calls a "fatal flaw," standing. A finding of abuse of process cannot exist independently of the question of standing, as "the threshold test for granting public interest standing will already have

Ibid at para 47. For other expressions of this central issue see ibid at paras 39, 53.

Ibid at para 52.

Ibid at paras 54, 57 .

Ibid at paras 72-87; Wildlife Act, supra note 14; Alberta Zoo Standards Committee, Government of Alberta Standards for Zoos in Alberta (Edmonton: Sustainable Resource Development and Alberta Agriculture, Food, and Rural Development, 2005) [GASZA]. Bisgould considers Alberta's regulations to be the most "comprehensive" zoo regulations in Canada (Bisgould, supra note 9 at 259).

Reece, ibid at paras 60-69. Suggested reforms include strengthened enforcement, a "living property" category, and the extension of liberty rights or legal personhood to animals.

Ibid at para 70 .

Ibid at para 90.

Ibid at paras 89, 91.

Ibid at para 91 .

Ibid at para 162.

Ibid at paras 71, 88-91.

Ibid at para 139. 
addressed the question of whether the relief sought is justiciable.”82 The second error follows from the first, as the Chambers Judge is said to have applied the incorrect test for abuse of process. Rather than asking whether it was "plain and obvious that allowing the appellants' action to continue would be contrary to the interests of justice," 83 he instead considered whether the case could come before the courts in another manner, thereby applying one element of the test for public interest standing. ${ }^{84}$

The dissent dismisses the claim that any private attempt to enforce a penal statute is an abuse of process. "[T]he mere fact that alleged unlawful acts by the City may be the subject of a prosecution under the Act is arguably not dispositive of whether the declaratory remedy sought is an abuse of process," ${ }^{85}$ Chief Justice Fraser states. She also addresses the procedural concerns by noting that the City would not be entitled to a full range of protections even were the case to be tried in the criminal realm, as the nature of charges under the Act (regulatory, rather than fully criminal) limit the application of protections under the Canadian Charter of Rights and Freedoms. ${ }^{86}$ Further, the City may not qualify for the protections in the first place: "[T]he Charter is designed to protect people from the state. It was never intended to protect the state from the people." ${ }^{\text {"7 }}$ The third identified error involves the summary dismissal of declaratory relief: "[W]hether a declaration against the City is available ... could not, and ought not, to have been resolved summarily. These issues are for a trial judge following a trial on the merits." 88

Finally, the dissent turns to the question of whether the Appellants qualify for public interest standing. Considering the first step in a three-part test, which asks whether "a serious issue [is] raised about the limits of administrative or statutory authority," the opinion emphasizes that the City's actions are "an exercise of administrative authority and they must remain within the limits of the City's statutory authority." 89 Further, the evidential record (incomplete, but admissible) suggests a serious breach of the Act. ${ }^{90}$ "This case is not about whether Lucy got one less load of hay for breakfast one day," "91 the opinion notes. Rather, the application paints a “disturbing image of the magnitude, gravity and persistence of Lucy's on-going health problems" rising out of "an alleged sustained pattern of conduct over time ... contrary to what the law requires." 92

On the second point, the dissent quickly determines that the Appellants, as devoted animal advocates, have the requisite "real and continuing interest in the City's compliance with its

\footnotetext{
Ibid at para 140 .

Ibid at para 146.

Ibid at para 145 .

Ibid at para 146 .

Part I of the Constitution Act, 1982, being Schedule B to the Canada Act 1982 (UK), 1982, c 11

[Charter]. See Reece, ibid at para 149.

Reece, ibid at para 165.

Ibid at para 168. The dissent explains why the claimed relief might be available at trial: multiple proceedings may be used for the same act, so a regulatory infringement would not bar a civil claim; a declaratory remedy may better address the breach than a criminal one; limiting remedies to regulatory proceedings could immunize government from scrutiny; and animal welfare enforcement may be best pursued through civil claims (ibid at paras 157-66).

Ibid at paras 172, 174.

Ibid at paras 92-103.

Ibid at para 95.

Ibid at paras 103, 95. The dissent reviews evidence relating to Lucy’s health at paras 103-26.
} 
legal obligations to Lucy."93 For the third step in the test, which asks whether there is an alternative method by which the issue could come before the court, the opinion dismisses various proposed alternatives; as Lucy herself cannot challenge the City's actions as a private litigant, no private interest standing can be granted and the actions of the Humane Society and the Attorney General indicate that an attempt at private prosecution would be stayed. ${ }^{94}$ Based on these points, the dissent would have granted the Appellants standing to request the declaration. ${ }^{95}$ Though this outcome did not result, the Chief Justice's decision offers animal advocates judicial validation on many points and delivers a shock to the traditional anthropocentric legal system.

\section{THE REMARKABLE NATURE OF THE DisSENT}

As the overview intimates, there are multiple features of the dissent that distinguishes it in Canadian animal law. In this section, three main categories of the judgment are discussed: its foundational reliance on the rule of law, its serious treatment of animal rights, and its recognition of animals' vulnerability.

\section{CONNECTION TO THE RULE OF LAW}

The first remarkable feature of this dissent is its treatment of animal interests as a rule of law issue. This occurs in the very first paragraph of the dissenting judgment where, after briefly referencing the conditions under which Lucy is forced to live in captivity, Chief Justice Fraser writes:

Some may consider this appeal and the claims on behalf of Lucy inconsequential, perhaps even frivolous. They would be wrong. Lucy's case raises serious issues not only about how society treats sentient animals - those capable of feeling pain and thereby suffering at human hands - but also about the right of the people in a democracy to ensure that the government itself is not above the law. ${ }^{96}$

With this direct and upfront statement, the dissent at the outset of the judgment connects what many still perceive to be a laughable or trivial interest - the treatment of animals to the classic liberal legal concern about the rule of law, a principle that is still venerated today as a pillar of a properly functioning and "civilized" society. ${ }^{97}$ As Canadian jurists have

Ibid at para 176 .

Ibid at paras 179-93.

Ibid at para 196.

Ibid at para 39 [footnote omitted].

The importance of the "rule of law" in measuring "civilization" in colonial and imperial histories cannot be understated; the perceived absence or presence of the "rule of law" helped to justify the marking of Western cultures and societies as more advanced than non-Western ones. For example, Sherene Razack shows how the "lawlessness" argument was used to justify violence perpetrated by Canadian "peacekeepers” in Somalia: see Sherene Razack, "From the 'Clean Snows of Petawawa': The Violence of Canadian Peacekeepers in Somalia” (2000) 15:1 Cultural Anthropology 127 at 142. Ratna Kapur demonstrates how notions of "civilization" persist in marginalizing people who are labelled as "migrant”: see Ratna Kapur, "The Citizen and the Migrant: Postcolonial Anxieties, Law, and the Politics of Exclusion/Inclusion" (2007) 8:2 Theoretical Inquiries in Law 537. John Borrows describes the misconception that indigenous peoples did not practice law prior to the arrival of Europeans. He goes on to show how this judgement is founded on prejudice: see John Borrows, "Indigenous Legal Traditions in Canada” (2005) 19 Wash UJL \& Pol'y 167 at 176-79. See also Piyel Haldar, Law, Orientalism and Postcolonialsim: The Jurisdiction of the Lotus Eaters (New York: RoutledgeCavendish, 2007); Peter Fitzpatrick, "Passions Out of Place: Law, Incommensurability, and Resistance” in Eve Darian-Smith \& Peter Fitzpatrick, eds, Laws of the Postcolonial (Ann Arbor: University of Michigan Press, 1999) 39. 
noted time and time again, the rule of law is a founding principle of the common law and both a written and unwritten constitutional norm; “[w]hether implicit or explicit ... the principle of the rule of law applies to the entire constitutional order and every part of government." 98 Indeed, Chief Justice Fraser asserts that the issues in the case ((1) when to grant citizens public interest standing to try to pursue a declaratory remedy that the government must enforce its animal welfare laws; and (2) when is a civil declaratory judgment an appropriate remedy when a quasi-penal law already exists to hold government to account) are "linked to a crucial issue in a constitutional democracy." "W9 While she does not reference him directly, in her phrasing in the last sentence - "to ensure that the government itself is not above the law" - Chief Justice Fraser appears to be channeling one of the most venerated figures in Canadian public law, Albert Dicey, and his iconic concern about government accountability and the separation of institutions and powers. ${ }^{100}$

In making this connection, the dissent elevates the relatively low level status of anticruelty statutes by imprinting the subject with rule of law importance. ${ }^{101}$ This is an unparalleled move in animal law jurisprudence in Canada. At its most progressive, the rule of law is typically associated with human rights accountability and transparency. ${ }^{102}$ Of course, Chief Justice Fraser's concern is tethered to the Appellants' ability to have the law enforced, not Lucy's ability. She nevertheless, and in a non-anthropocentric manner, connects the human interests here in the rule of law to animal interests. This occurs at multiple points in the judgment. For example, she affirms that the rule of law issues outlined in the paragraph above are "fundamental to the effective protection of animals in this province.”103 More concretely, later in the judgment, she writes:

[C]ourts should not diminish the full import of animal protection laws by creating unnecessary barriers to those seeking to ensure compliance with them. Animals, including Lucy, cannot commence lawsuits on their own to protect themselves. They must rely on humans to give voice to the truly voiceless. Thus, courts should

Colleen M Flood \& Lorne Sossin, eds, Administrative Law in Context (Toronto: Emond Montgomery, 2008) at 90. See also Guy Régimbald, Canadian Administrative Law (Markham: LexisNexis, 2008) at 179 ("courts have continuously affirmed their inherent right as protectors of the will of Parliament and the rule of law in controlling any decision maker's exercise of discretion" [emphasis in original]). For a fuller discussion on rule of law, see generally David Dyzenhaus, ed, Recrafting the Rule of Law: The Limits of Legal Order (Portland: Hart, 1999).

$99 \quad$ Reece, supra note 7 at para 47.

100 See e.g. AV Dicey, Introduction to the Study of The Law of the Constitution, 6th ed (London: Macmillan and Co, 1902) at 179-201 (writing in 1902, Dicey describes the legal landscape as such: "Parliament has looked with disfavour and jealousy on all exemptions of officials from the ordinary liabilities of citizens or from the jurisdiction of the ordinary Courts; Parliamentary sovereignty has been fatal to the growth of 'administrative law'” ibid at 353). For an overview of Dicey's rule of law model and the legal principles that remain relevant today see e.g. Flood \& Sossin, supra note 98 at 80-81. See Bisgould, supra note 9 at 120.

102 The presence (or absence) of rule of law has recently, once again, become an issue of debate. The "war on terror" and its various manifestations have brought to the forefront questions about the unequal application of rule of law and how the decision to respect or forego legality acts to empower or marginalize. See e.g. Sherene H Razack, Casting Out: The Eviction of Muslims from Western Law \& Politics (Toronto: University of Toronto Press, 2008). Razack explains how "[l]egal measures that suspend rights in the interests of national security have been variously described as state-of-exception, state-of-emergency, war measures or state-of-siege measures” and that despite their semantic differences, "they share the paradox that they are laws that suspend the rule of law": ibid at 11. These measures, argues Razack, are justified through racialized and gendered rhetoric, such that "[w]e become inured to lawlessness, as long as it remains in the camps, as long, that is, that it is only applied to certain bodies": ibid at 58 . 
take a generous, not impoverished, approach to the grant of public interest standing for those attempting to enforce the restrictive animal rights that do exist. ${ }^{104}$

In Chief Justice Fraser's view, a generous reading of public interest standing law is required not just to respect the rights of humans who wish to pursue their passions and causes, but also because animals have no other way of having their voices heard in the human justice system other than through human representatives. Chief Justice Fraser reiterates this point yet again in the course of discussing the merits of proceeding civilly for a remedy in view of the City's argument that doing so would violate its Charter rights. ${ }^{105}$ She responds that a civil remedy may be necessary when the state does not hold itself to its own (animal welfare) laws. ${ }^{106}$ Chief Justice Fraser implies that otherwise there may be no remedy; she asks rhetorically: "Is there no one who can intervene under any circumstances no matter how egregious to protect vulnerable animals from mistreatment by government?"107

Clearly, the importance Chief Justice Fraser places on a generous and responsive approach to public interest standing correlates not just to human interests in rule of law values, but animal interests in being protected from harm at the hands of government actors. Rule of law as a principle is extended to the direct interests of animals, thus imbuing an anti-cruelty statute with constitutional importance.

\section{SERIOUS TREATMENT OF THE ANIMAL RightS CRITIQUE}

In addition to ascribing animal issues with rule of law stature, the dissent is also distinctive in Canadian jurisprudence because of the seriousness with which Chief Justice Fraser treats the range of positions in the debate among animal scholars over how to proceed with animal law reform. ${ }^{108}$ Specifically, she legitimates critiques of the current welfarist model including the animal rights position that seeks abolition of all industries and practices that exploit animals.

The Chief Justice undertakes a fulsome review of the animal law developments to date under Part II of her judgment, noting the genesis of anti-cruelty legislation, ${ }^{109}$ as well as the "welfarist-abolitionist" debates in the scholarly literature between those who believe

Ibid at para 90 [footnotes omitted].

Chief Justice Fraser explicitly acknowledges the perverted nature of the City's Charter arguments: "The underlying purpose of the Charter is premised on the assumption that the state - that is government - wields substantial powers against its citizens. Thus, the Charter is designed to protect the people from the state. It was never intended to protect the state from people": ibid at para 165. Commenting on the potential for the Charter to be re-routed to serve state interests, Andrew Petter writes: "What disturbs me is that such tendencies seem to have become endemic and that politicians and other public officials are turning to the Charter with increased regularity to justify or avoid taking positions on contentious issues, to shift political responsibility to the courts, and to try to discredit the political views of others" (Andrew Petter, "Legalise This: The Chartering of Canadian Politics" in James B Kelly \& Christopher P Manfredi, eds, Contested Constitutionalism: Reflections on the Canadian Charter of Rights and Freedoms (Vancouver: UBC Press, 2009) 33 at 46).

Reece, ibid at para 162.

Ibid.

Even though Chief Justice Fraser refrains from providing her personal opinion on the academice debate surrounding animal welfarism, "the incontrovertible fact of its very existence is the point" (Bisgould, supra note 9 at 121).

Reece, supra note 7 at paras 54-55. The judgment also quotes Jeremy Bentham's oft-quoted question in animal ethics literature: "[T]the question is not, Can they reason?, nor, Can they talk?, but, Can they suffer?” (ibid at para 54, n 23). 
incremental welfarist legislation can lead to meaningful and lasting change for animals (welfarists) and those who believe that all instrumental use of animals must end for such change to occur (abolitionists). ${ }^{110}$ She characterizes anti-cruelty offences as not only targeted at preventing abuse, but also bestowing duties on owners to take care of their animals' basic needs. ${ }^{111}$

In this discussion, Chief Justice Fraser characterizes the present animal welfare model as not "exploitative," if compared to a time when no such laws existed, but she also notes the problems with the model. ${ }^{112}$ She states that the "animal welfare model continues to be the norm in Canada today," 113 and then devotes considerable space to canvassing how this model is said to fall short of properly protecting animals. She specifically sets out a subheading in Part II to emphasize what commentators have noted as "flaws" in the current "animal welfare model." " Here she points to the "delimiting qualifications" 115 of the typical wording of anticruelty offences that are quick to excuse suffering, as well as the anthropocentric nature of the utilitarian calculus that informs the scope of suffering. ${ }^{116}$ She further notes that the laws, weak as they are in this area, are poorly enforced and that animal organizations have had a difficult time in receiving public interest standing to protect animals. ${ }^{117}$ The Chief Justice then reviews proposals to improve the laws that have been advanced. ${ }^{118}$ In these discussions, Chief Justice Fraser states that "it must be conceded that the basic animal welfare model still involves attempting to balance animal pain against human need or pleasure."119 Although she follows this statement with the reasoning that the extent to which such balancing should be revisited "is largely a question for the Legislature," ${ }^{120}$ she does legitimate the possibility that the Legislature may wish to replace the instrumentalist model with one more oriented toward animal rights. $^{121}$

Perhaps most importantly, Chief Justice Fraser includes Francione’s abolitionist critique in her list of proposals for reform. She presents the position as one that questions the efficacy of anti-cruelty statutes in general due to their reinforcement of the property status of animals and calls for legal subjectivity for all animals. ${ }^{122}$ While she characterizes the abolitionist critique as occupying one "end of the reform spectrum" $" 123$ compared to more incremental suggestions, nowhere does she cast this animal rights position as excessive or otherwise discount its validity in the overall debate. Rather, she incorporates the fundamental critique of the property status of animals into her reasoning about the multiple deficiencies with the

For a full treatment of this debate by two influential figures, one representing each side, see Gary L Francione \& Robert Garner, The Animal Rights Debate: Abolition or Regulation (New York: Columbia University Press, 2010).

Reece, supra note 7 at para 56.

Ibid at paras 54-55.

Ibid at para 56.

Ibid at paras 54-64. Bisgould emphasizes the significance of the Chief Justice's critique of anti-cruelty legislation, writing that it "provides interim support for a significantly broader interpretation of existing legislation that has animal protection as its aim": Bisgould, supra note 9 at 118.

Reece, ibid at para 60.

Ibid at para 61.

Ibid at paras 62-63.

Ibid at paras 65-70.

Ibid at para 57.

Ibid.

Ibid.

Ibid at para 69.

Ibid. 
current welfarist model that collectively call for legal attention rather than continued dismissal. In concluding her contextual analysis in Part II, Chief Justice Fraser writes:

\begin{abstract}
The criticisms about the animal welfare model touch on how it is actually applied in real life at various stages of the legal process: inadequate consideration of animals' interests in law-making; priority for human interests always; restrictive judicial interpretation of protective legislation; common law precepts that treat animals as property and deny them or their advocates legal standing; limitations on what constitutes legitimate legal argument; restrictions on what is accepted as evidence; and anaemic enforcement of animal protection legislation. Understanding the nature and extent of these deficiencies - more than one of which is arguably at play in this case - is important since they underscore why courts should interpret the animal protection laws we do have generously and why this case raises novel points of law not suitable for summary dismissal. ${ }^{124}$
\end{abstract}

By including "common law precepts that treat animals as property" in this closing paragraph noting the various shortcomings of the welfarist model, Chief Justice Fraser affirms the severe limitations that animals' property status pose to how animals are treated under anti-cruelty statutes. She notes animals’ property status as an additional problem to the general anthropocentric valuation engrained in the current legal system and urges a greater judicial role in responding to this weighted dynamic against animals in the type of litigation before her.

In this capacity, Chief Justice Fraser is the first Canadian judge to not only robustly discuss criticisms of the current legal framework for animals, but is also the first jurist to treat the animal rights framework that seeks to abolish animals' property status as a serious model worthy of legal and judicial attention. She presents all of this discussion as valuable context to understanding and interpreting the existing Alberta law. ${ }^{125}$ By doing so, she invites both legislative and judicial take-up of the "welfarist-abolitionist" debate, which — if such institutional engagement occurred - could have significant impact for animals if the abolitionist approach attracted more support.

\title{
3. RECOGNITION OF ANIMALS’ VuLNERABILITY
}

The third reason Chief Justice Fraser's dissent departs from the traditional legal objectification of animals, despite having to work within the confines of a welfarist statute, flows from her representation of animals as sentient and vulnerable beings in need of a legal voice. Here the judgment goes further than the handful of other instances of explicit recognition of animal sentience or difference from other forms of property in Canadian legal discourse. ${ }^{126}$ The Chief Justice's appreciation of animals as sentient and relational is evident

124

Ibid at para 71.

Ibid at paras 51-53, 71.

There are other instances where Canadian courts have recognized the sentience of animals, however these discussions have mostly been contained within an anthropocentric framework. For example, in Rogers v Rogers, [1980] OJ no 2229 (QL), the Court heard a custody dispute over a companion dog. The Judge found that, "a dog has feelings, is capable of affection, needs to be shown affection and that its affection can be alienated" (ibid at para 28), and went on to decide where the dog should live based partly on the best interests of the animal. That the animal in question was a companion to humans is not insignificant, nor is the evidence tendered to show the benefit of the animal to its guardians. Wild animals have also been the subject of sentience discourse; in Diversified Holdings Ltd v British Columbia, [1982] 133 DLR (3d) 712, the Judge displayed a form of connectedness to the elk at issue in the case. He describes the issue of the case as such: "[T]he elk over the period acquired a taste for the 
in her descriptions of elephants in general and her focus on the degree of vulnerability experienced by these beings. Indeed, the judgment begins with this acknowledgment and the entire decision appears directed by the foundational principle contained in the first sentence: “An elephant is a social animal."127 By opening with this statement, Chief Justice Fraser affirms a relational subjectivity for elephants. Yet, the decision is not limited to elephants as the ensuing discussing embraces all sentient animals. ${ }^{128}$ Chief Justice Fraser is acutely aware of the vulnerability created for all animals through the ownership dynamic:

Animals over whom humans exercise dominion and control are a highly vulnerable group. They cannot talk — or at least in a language we can readily understand. They have no capacity to consent to what we do to them. Just as one measure of society is how it protects disadvantaged groups, so too another valid measure is how it chooses to treat the vulnerable animals that citizens own and control. ${ }^{129}$

Chief Justice Fraser underscores the scope for abuse and intimates the violence that can be enacted against animals by way of human ownership over them. The dependence that animals owned by humans experience exposes them to a level of vulnerability that the Chief Justice views as parallel in importance to the vulnerability of human disadvantaged groups. Emphasizing the vulnerability of animals in Canadian society and comparing it to that which human beings experience communicates an unparalleled level of judicial respect for animals as subjects in their own right. ${ }^{130}$

new enriched fodder.... [D]enied such creature comforts, [they] decided to roam the valley looking for a new source of supply.... Knowledge of the new feeding source quickly spread among the elk, and in a short time the herds adopted the practice of gathering at the ranch for their evening meal, a night's rest and a substantial breakfast" (ibid at 714). There are also examples of judges who recognize the political and legal consequences of ignoring the sentience of animals. For example, in $R v$ Ringler, 2004 ONCJ 104, 122 CRR (2d) 15 [Ringler], the Court recognized the movement to change the property status of animals in the Criminal Code, and even lends support for this initiative. The Judge states: "With regard to the question of where, on the hierarchy or continuum, of our society an animal is positioned, it was quite correctly acknowledged by the Crown that an animal was not at the same level as a human being, that it is of a lesser status.... Although an animal is lower on the hierarchy, from a human being, it is not at the bottom, such as a piece of static property" (ibid at para 21). Similarly, in $R v$ Munroe, 2010 ONCJ 266, [2010] OJ no 2579 (QL) at para 23 [Munroe], the Judge refers to the sentience of animals and articulates the responsibility of human owners toward animals: "Society has long ago moved forward from the notion of animals as mere property. While man continues to have dominion over animals, in a civilized society that is a power accompanied by significant responsibilities.” The US has seen a similarly narrow recognition of the sentience of animals within the jurisprudence. In United States $v$ Robert J Stevens, [2008] 533 F (3d) 218 at 230 (3rd Cir 2008) the Judge recognizes sentience, but differentiates the potential harm to animals from the more complex suffering for which humans are capable. This narrow conceptualization of animal suffering is also found in Oberschlake $v$ Veterinary Associates Animal Hospital, 785 NE (2d) 811 at 814 (Ohio Ct App 2003). In Bueckner v Hamel, 886 SW (2d) 368 at 377-78 (Tex Ct App 1994) companion animals are recognized as forming a "unique category of 'property' that neither statutory law nor caselaw has yet recognized" as they are "sentient and emotive beings that are capable of providing companionship to the humans with whom they live." This "in-between" status of animals is also echoed in the decision of Scheele $v$ Dustin, 2010 VT 45 at para 17. Finally, in Mateas v Fred Harvey, 146 F (2d) 989 at 994 (9th Cir 1945) the dissenting Judge finds that "[a] mule is not a machine but a sentient animal."

Reece, supra note 7 at para 39.

Ibid.

Ibid at para 88.

Ibid at para 72. Some may object to the comparison of the suffering of animals to the suffering of humans because it is disrespectful to humans. This criticism, of course, usually stems from the anthropocentric premise that animals are inferior to humans. For posthumanist responses to this criticism defending the drawing of nuanced comparisons, see Cathryn Bailey "We Are What We Eat: Feminist Vegetarianism and the Reproduction of Racial Identity” (2007) 22:2 Hypatia 39 at 44-58; David Sztybel, "Can the Treatment of Animals be Compared to the Holocaust?” (2006) 11:1 Ethics \& the Environment 97; Maneesha Deckha, "Intersectionality and a Posthumanist Vision of Equality” (2008) 23:2 Wis JL Gender \& Soc’y 249 at 259-61. 
Respect for the subjectivity of sentient animals is also conveyed through the dissent's willingness to represent animals in a non-objectifying and non-anthropocentric fashion. The Chief Justice depicts elephants as complex beings, devoting an entire paragraph to a description of the capacities of elephants — such as "distinguishing amongst the various voices of their relatives and companions; empathizing with others; discriminating between friendly and unfriendly people and other animals; and using and even manufacturing small tools" ${ }^{131}$ — and acknowledging the perceived social organization among these animals. The dissent even destabilizes the common anthropocentric narrative that animals do not use language, a common reason proffered to justify human uniqueness and corresponding social, legal, and cultural anthropocentric orders. ${ }^{132}$ Instead, she subverts the normalized anthropocentric perspective by noting that animals do use language, but that our limits with human languages prevent our understanding of what animals are saying. Chief Justice Fraser resorts to anthropomorphic terms such as "mothers, daughters, granddaughters, sisters"133 to describe elephants' social relations, again, not to promote an anthropocentric view, but to present the elephants' importance intrinsically to themselves and to other beings in their communities. $^{134}$

This general understanding of animals as vulnerable and of elephants as having multiple and complex needs does not preclude a focus on Lucy's individual situation. Chief Justice Fraser proceeds to evaluate Lucy's life against the requirements and capacities that the Chief Justice has presented as owed to elephants generally due to their status as vulnerable beings subject to human control. Her empathy for Lucy as an individual is evident in the attention paid to the particular details of Lucy's life, discussed above, and the real consequences of this case on her life. ${ }^{135}$ Before detailing how Lucy was brought to Canada and how she has only intermittently had the companionship of other elephants and now suffers multiple pressing chronic conditions, ${ }^{136}$ Chief Justice Fraser speaks to the effect these circumstances have had on Lucy overall:

[T]he affidavit evidence packs a powerful punch. It holds up a mirror for all to see — provided one is prepared to look into the mirror. What it reveals is a disturbing image of the magnitude, gravity and persistence of Lucy's on-going health problems and the severity of the suffering she continues to endure from the conditions in which she has been confined. And it also exposes who is responsible for those conditions and that suffering. ${ }^{137}$

Reece, ibid at para 104.

See e.g. Marie Fox, "Re-thinking Kinship: Law’s Construction of the Animal Body” (2004) 57:1 Curr Leg Probs 469 at 479: "In addition to exposing the suspect nature of legal classifications, the (supposedly) special capacities of boundary animals suggest that any of the markers traditionally invoked to separate humans from animals (such as self-consciousness, rationality, language use, toolmaking capacity, etc.) are fallible.”

Reece, supra note 7 at para 104.

The pitfalls of the Chief Justice's anthropomorphic reasoning are discussed below, in Part E.

Reece, supra note 7 at paras 105-107.

Ibid. The depth of the Chief Justice's sympathy for Lucy is evident in her use of the language of imprisonment when describing the elephant's situation: “Absent a same species companion for Lucy, this amounts to Lucy's having been kept in solitary isolation - some might use the words solitary confinement - since Samantha was moved away" (ibid at para 106).

Ibid at para 103. Bisgould refers to this passage as "Fraser's Mirror" and advocates for this mirror to be used to see the exploitation of all animals in Canada: Bisgould, supra note 9 at 285. 
This quote captures the compassion and respect the Chief Justice has for Lucy, whom she recognizes as a fellow sentient being, and her willingness to hold accountable those who exploit animals for profit. ${ }^{138}$ Forceful descriptors like "magnitude, gravity and persistence," used to describe Lucy's ailments, display the depth of the Chief Justice's perception of Lucy as a vulnerable individual who is being harmed by those who have the responsibility to care for her.

The dissent retains this strong respect for Lucy's subjectivity in discussing the details of the evidentiary record. Chief Justice Fraser begins by offering a substantial introduction to Lucy's life as a lone elephant suffering in a cold climate, emphasizing the social nature of female elephants and the detrimental impact Lucy's imposed isolation has on her as a female elephant. ${ }^{139}$ Drawing from the affidavit evidence presented, ${ }^{140}$ she describes Lucy as suffering from a "litany of painful, debilitating medical conditions that she has apparently endured for years." ${ }^{141}$ She then devotes 20 paragraphs to discussing the medical evidence available regarding the above conditions and connecting the conditions to the requirements in the Act regarding adequate shelter and space. ${ }^{142}$ Chief Justice Fraser comes to the conclusion that, "[a]t 36 years of age, Lucy should be in the prime of her elephant life. She is not."143

By applying her finding that elephants in general are sentient beings with social needs to document and narrate the abject nature of Lucy's situation specifically, the Chief Justice affirms Lucy's status as an individual subject whose suffering deserves attention and, given the mandate of the Act, an opportunity for legal redress. ${ }^{144}$ When Chief Justice Fraser's reasoning about animal vulnerability is combined with her affirmation that how humans treat animals is a topic that engages rule of law considerations and that the current legal status of animals is in need of judicial scrutiny, the non-anthropocentric turn in the dissent is palpable.

\section{E. REMARKABLE - REALLY?}

Despite all of these features that demonstrate the dissent's resistance to the traditional legal instrumentalist view of animals, it may be suggested that "remarkable" is too strong an adjective by which to characterize Chief Justice Fraser's dissent in terms of its contribution to a non-anthropocentric jurisprudence. This section, gives attention to these anticipated objections and suggests why the descriptor and positive appraisal still hold.

Referring to the empty promises made by the City, Chief Justice Fraser writes: "The uncontradicted facts here reveal that four years after the City removed Samantha from the Valley Zoo, Lucy remains by herself, socially isolated. And again on this uncontradicted record, nothing has been done to deal properly with a number of other complaints concerning the way in which Lucy is being housed and sheltered by the City" (Reece, ibid at para 189). Ibid at para 103.

The Chief Justice is aware that the affidavit evidence may be contested at trial, but accepts it for the purpose of the appeal before her (ibid at para 103). Ibid at para 107. As the Chief Justice notes, the list "includes chronic respiratory problems, arthritis (stiffness, swelling, soreness, lameness, pain), foot disorders and obesity”: ibid [footnotes omitted]. Ibid at paras 107-18.

Ibid at para 127.

The strong legal reasoning of Chief Justice Fraser's dissent has been recognized as augmenting the potential that this decision will be "the source of important legal developments to come": Bisgould, supra note 9 at 123 . 


\section{ELEPHANTS AS “HONOURARY HUMANS”}

An initial consideration that may temper enthusiasm for the dissent from an animal-centric perspective arises from Lucy's membership in a species that, vis-à-vis most other nonhuman species, enjoys an elevated cultural status. Lucy is an elephant and elephants loom large not only as a physical presence in wildlife habitats across the world, but also in our cultural imaginaries. They are part of the megafauna toward which many cultures express a high regard, ${ }^{145}$ typically higher than that extended to other animals and even approximating an "honourary" human status (dolphins, whales, and primates also fall into this category). ${ }^{146}$ Best-selling books and films revolve around the lives of elephants emphasizing the breadth of their cognitive and emotional capacities in relating to humans and interrelating amongst themselves. ${ }^{147}$ Indeed, as we have seen, Chief Justice Fraser emphasizes elephants’ cognitive and social skills in her judgment. Lucy then, was in some ways an ideal animal "litigant" to take this litigation forward. ${ }^{148}$ She belongs to one of the nonhuman "wild" species that Westerners commonly romanticize rather than stigmatize. ${ }^{149}$ The realization that she is now captive and suffering disturbs culturally informed sensibilities in a way that the living conditions of other, less culturally popular, animals would not.

The hierarchization of nonhumans is not new and neither is the cognitive dissonance surrounding what type of treatment of animals is socially or legally acceptable. ${ }^{150}$ Indeed, the private law developments discussed briefly above and the Chief Justice's discussion about elephants' capacities may be said to illustrate the divide between what Cary Wolfe calls “animalized animals" and "humanized animals." 151 Had the appellants initially complained to the Humane Society about the condition in which one of the reptiles (not a strong cultural favourite of most Albertans, or Canadians for that matter, and thus an "animalized animal”) or one of the birds (much smaller than the megafauna who typically elicit our cultural favour), the dissenting judgment may have been different. Chief Justice Fraser may indeed have reached the same conclusion, but it seems likely that she would have had to do more

For an overview of the issues surrounding the popular focus on "charismatic megafauna,” see e.g. Daniel Lunney, “Charismatic Megafauna” (2012) in The Berkshire Encyclopedia of Sustainability: Ecosystem Management and Sustainability, online: Berkshire Publishing <http://www.berkshirepublishing.com/ brier/CharismaticMegafaunaLunney.pdf $>$.

146 The debate around "personhood” for these animals illustrates this point. See e.g. David DeGrazia, “Great Apes, Dolphins, and the Concept of Personhood” (1997) 35:3 The Southern Journal of Philosophy 301.

147 See Barbara Gowdy, The White Bone (Toronto: HarperPerennial, 2007); Sara Gruen, Water for Elephants (Chapel Hill, NC: Algonquin Books, 2007); David Denby, "Water for Elephants" The New Yorker, online: The New Yorker <http://www.newyorker.com/arts/reviews/film/water_for_elephants_ lawrence>.

148 The idea of the "ideal litigant" has been expressed in other strategic social movement litigation. See, for example, the discussion regarding the careful process to find the ideal plaintiff for the landmark US abortion case in Roe v Wade, 410 US 113 (1973). See e.g. David J Garrow, Liberty and Sexuality: The Right to Privacy and the Making of Roe $v$ Wade (New York: Macmillan, 1994) at 399-407.

149 Indeed, it seems plausible to conclude that the culturally high status of elephants forms part of the reasons Lucy was in a zoo in the first place as well as why the Valley Zoo did not want to give her to the sanctuary - elephants are a big attendance, and thus revenue, draw for zoos. For example, when the Cleveland Metroparks Zoo opened their African Elephant Crossing exhibit they recorded the highest zoo attendance in years: James Ewinger, "Elephants Give Cleveland Metroparks Zoo jumbo attendance Numbers" The Plain Dealer (2011) online: cleveland.com <http://blog.cleveland.com/metro/2011/ 06/elephants_give_cleveland_metro.html>.

150 Taimie L Bryant, "Similarity or Difference as a Basis for Justice: Must Animals be like Humans to be Legally Protected from Humans?” (2007) 70:1 Law \& Contemp Probs 207 at 210: “[T]he similarity argument promotes pernicious hierarchical ordering of nonhuman animals based on their relative proximity to humans."

151 Cary Wolfe \& Jonathan Elmer, "Subject to Sacrifice: Ideology, Psychoanalysis, and the Discourse of Species in Jonathan Demme’s Silence of the Lambs” (1995) 22:3 Boundary 2141 at 145-47. 
in her reasoning to make her audience care, even legally, about a reptile or small bird, and citizens' rights to act on those animals' behalf.

Certainly, had Lucy been a reptile or small bird, the dissent for this reason would have been even more remarkable. The Chief Justice would not have been able to so easily rely on the humanist values that make Lucy an appealing animal "victim.” To reiterate a point made at the outset, the dissent challenges anthropocentrism, not humanism. Resistance to the concept of a species hierarchy and to the human dominion claims that ground law's instrumentalist view of animals is apparent throughout the judgment as discussed above. Rejection of humanist concepts of what matters ethically and legally, however, is not. Recall how the dissent marshals comparisons with human suffering and human capacities to convey the seriousness of Lucy's condition. Lucy is an elephant whose abject circumstances were made intelligible by the dissent primarily through humanist norms of what and who matters. This capitulation to humanism's hegemonic force in the law, however, does not preclude the dissent offering a groundbreaking turn against the law's conventional anthropocentric worldview in terms of recognizing the vulnerability of animals and legitimating the need for animal law reform. ${ }^{152}$

To be sure, the dissent could have gone much further in this recognition and legitimation. Recall that the Chief Justice states the familiar refrain that it is the role of the legislature, not the courts, to address the larger issue of how humans should treat animals in different industries and contexts. ${ }^{153}$ This seems to foreclose the opportunity for a generous approach to novel situations involving the vulnerable group of animals that Chief Justice Fraser calls for elsewhere in the decision and is critical to the ruling she would have reached. While the larger issue of animals' legal status is not before her and thus could not be expected to have been judicially addressed, it is foreseeable that a future case may come forward where this question arises and where judicial intervention arguably has a role to play in social change, especially on the part of vulnerable groups who do not carry much voting capital with the legislature. Past and present examples tell us that courts have intervened time and time again in social controversies of the day and that the judicial reference to institutional roles to decide or, really, to defer a matter, is seldom persuasive to seasoned readers. ${ }^{154}$

I am also well aware that Lucy is not a "food" animal and thus not part of that group of animals whose conditions of life and death are abysmal. Animal welfare provisions are widely assumed not to apply to agricultural industries and, as I have mentioned earlier, animals exploited within these industries are explicitly exempted in the provisions. See e.g. British Columbia's PCAA, supra note 8. Similarly, consider the American Animal Welfare Act, which specifically excludes both agriculture and research industries from its purview (Transportation, Sale, and Handling of Certain Animals, 54 USC 7 § 2132(g) (2009)). Searches in Canadian legal databases failed to uncover records of any anti-cruelty prosecutions against the agricultural industries. Yet, it is not fair to undermine the impact of Chief Justice Fraser's dissent on this ground either. Working within the incremental paradigm of judicial reform, she can only deal with the facts presented before her. The fact here was that Lucy was a zoo animal and not a food animal. Indeed, one of the strengths of the judgment, as reinforced above, is Lucy's status as a non-companion animal. Reece, supra note 7 at para 57.

For example, the recent case regarding Insite, a safe injection site in Vancouver, brought the question of institutional roles to the discussion: see e.g. Jeremy Webber, "Section 7, Insite and the Competence of Courts” (2011) 19:3 Const Forum Const 125. Another controversial issue which has recently seen judicial attention is that of physician-assisted suicide. Consider Rodriguez v British Columbia (AG), [1993] 3 SCR 519 [Rodriguez] in comparison with the very recent Carter v Canada (AG), 2012 BCSC 886, 287 CCC (3d) [Carter]. In the first, the Supreme Court of Canada declined to change the law prohibiting physician assisted suicide. In the second, the British Columbia Supreme Court recognized a constitutional infringement and enforced legislative change, despite the fact that the prohibition has often been discussed in the legislature and continues to be upheld. This issue makes visible both the 


\section{ACCEPTANCE OF ZOOS AND WELFARIST LEGISLATION}

Perhaps the most "unremarkable" feature of the dissent is that it does not adopt an abolitionist position toward zoos. Despite ample academic critique, it does not address the legitimacy of zoos as an institution to examine the practice of permitting zoos in the first place and their inherent placement of wild animals in captivity for human ends. ${ }^{155}$ Rather, the dissent seeks to enforce the legislation regulating the treatment of animals in zoos, which is welfare legislation. The "rights" Chief Justice Fraser identifies within this set of statutes and regulations are limited for this reason. ${ }^{156}$ They do not measure up to "rights" as that term is normally used in relation to human entitlements, which is why abolitionist scholars do not identify them as such. ${ }^{157}$ Indeed, the crux of the minority judgment is that the government is not respecting the existing (welfarist) law it saw fit to enact. The dissent stays within the four corners of the property-reinforcing legislation. These are certainly shortcomings from an abolitionist and animal-centric perspective.

Yet, it must be acknowledged that had the dissent adopted an abolitionist position, it would have been difficult to sustain and very likely to have been overturned on appeal given the lack of precedent available to reach a holding that the Valley Zoo and all zoos in Alberta should be shut down and the animals sent to sanctuaries. ${ }^{158}$ There is no Canadian legislative or constitutional document that incorporates principles about animal liberty, let alone dignity or equality, from which a Canadian judge can draw to interpret welfare legislation or that can trump the ownership rights the zoo retains in Lucy. There is also not yet even a handful of cases in Canadian law that conceptualize animals either on an individual or group basis as anything other than property. Further, there is no external jurisdiction model that Chief Justice Fraser may have invoked on a comparative basis that has abolished zoos or declared animals not to be property. ${ }^{159}$ At the most, she could have attempted to bolster this line of

hesitation from the judiciary to challenge normative jurisdictional lines drawn around contentious social issues, and the legal grounds upon which such a challenge can be justified. The majority in Carter distinguished the case from Rodriguez by acknowledging that "the emergence of the principles of fundamental justice relating to gross disproportionality and overbreadth marks a change from the state of the law at the time of Rodriguez": Carter, ibid at para 973.

155 Many zoo advocates point to the educational benefit that zoos have in cultivating progressive consciousness toward the animals inside and the global issues their species face. For a critique of the basis of this type of defence for captivity see John Sorenson, About Canada: Animal Rights (Winnipeg: Fernwood, 2010) at 113-17. For a critique of the colonial origin of zoos and their impact in perpetuating a colonial mindset toward so-called exotic cultures and their natural inhabitants, see Kay Anderson, "Animals, Science, and Spectacle in the City" in Jennifer Wolch \& Jody Emel, eds, Animal Geographies: Place, Politics, and Identity in the Nature-Culture Borderlands (New York: Verso, 1998) 27. For a relational consideration of the ethics of keeping animals captive see Lori Gruen, Ethics and Animals: An Introduction (Cambridge: Cambridge University Press, 2011) at 130-58.

$156 \quad$ Reece, supra note 7 at paras 72-87.

157 See e.g. Gary L Francione, “Animal Welfare and the Moral Value of Nonhuman Animals” (2010) 6:1 Law, Culture and the Humanities 24 at 35-36. Chief Justice Fraser is aware of this criticism yet uses the term anyway. This may be due to the term's power in conveying the importance of the interests at stake in general (Reece, supra note 7 at para 43, n 10).

158 Even sanctuaries can provide pause for animal advocates weighing options for animals: see Gruen, supra note 155 at $158-62$.

159 However, there are countries where the practice of exploiting animals for human entertainment has been significantly curtailed, such as India where circuses are not allowed to use certain animals: Balakrishnan v Union of India, High Court of Kerala (6 June 2000), online: Environmental Law Alliance Worldwide $<$ http://www.elaw.org/node/1831>. While the dissent could have referenced this development, it is likely to encounter resistance to the characterization of zoos as "entertainment"; indeed, many zoos claim that "education" is their primary mission. For a discussion of these claims and a critical reading of them, see John Sorenson, "Monsters: The Case of Marineland" in J Castricano, ed, Animal Subjects: An Ethical Reader in a Posthuman World (Waterloo: Wilfred Laurier University Press, 2008) 195 at 209-18. There are a few civil law jurisdictions where animals have been declared not to be called things for certain 
reasoning through certain select international initiatives that aim to recognize animal sentience, dignity, and moral status, but it must be noted that even these initiatives have not managed to escape a welfarist interpretation in their own jurisdictions. ${ }^{160}$

Although her dissent does not disrupt the present welfare legal regime for animals, Chief Justice Fraser does try to extend it beyond the typical understanding that informs the welfare model. It must be recalled that she is the first Canadian jurist to candidly admit the anthropocentric nature of the welfare model as well as the moral failings of anthropocentrism in relation to animals. Consider that after stating that the replacement of the welfare model with an animal rights one is a question that the legislature is best positioned to consider, ${ }^{161}$ she also writes:

\begin{abstract}
That said, in examining the arc of history and the relationship between humans and animals, it is clear that the development of the law has been influenced, and will continue to be, by mankind's deepened understanding of our place in the universe. Humans may be at the top of the evolutionary chain. But with rights come responsibilities and one of them is that we are the stewards of the environment. That stewardship is reflected in the legal obligations we have assumed not only to the physical biosphere but also to the animals with whom we share the Earth. Should moral, ethical or spiritual considerations not serve as adequate motivation in shaping those legal obligations, then the fact that this also happens to be in humanity’s own collective enlightened self-interest ought to suffice. Indeed, all evidently have. ${ }^{162}$
\end{abstract}

This passage encapsulates the dissent's departure point for the entire analysis. It showcases Chief Justice Fraser's awareness of the problems with an anthropocentric worldview and casts ambivalence, albeit subtly, on the "truth" that humans sit at the apex of a species hierarchy with the word "may.” It also associates rights with responsibilities and thus tempers the traditional property model assuming dominion and possession over animals with a relational understanding that instead emphasizes shared space and relationships between different types of beings. ${ }^{163}$

purposes. However, the purpose of this declaration is to distinguish them from inanimate objects. See Sabine Lennkh, "The Animal: A Subject of Law? A Reflection on Aspects of the Austrian and German Juridical Systems” (2011) 24 Int J Semiot Law 307 at 313.

Countries such as Switzerland and Germany have included animals in their constitutions, but so far these provisions have been read within a welfare framework. See e.g. Erin Evans, "Constitutional Inclusion of Animal Rights in Germany and Switzerland: How Did Animal Protection Become an Issue of National Importance?” (2010) 18:3 Society \& Animals 231.

$161 \quad$ Reece, supra note 7 at para 57.

$162 \quad$ Ibid at para 58.

$163 \quad$ Ibid. See also para 88: “Animals over whom humans exercise dominion and control are a highly vulnerable group.” Bruce Ziff describes the notion of property as "a state-enforced right of exclusion over things, good (generally) against the world”: Ziff, supra note 12 at 6 . Academics in all areas of law challenge this "right of exclusion," identifying property as a vehicle for exploitation. For example, Jennifer Nedelsky questions whether property status is the appropriate legal classification for reproductive material. She articulates the presumptions of this designation as being that "property in our system is the primary means of designating which things are to be treated as commodities - and exploitaiton, since our current system is premised on economic inequality": Jennifer Nedelsky, "Property in Potential Life? A Relational Approach to Choosing Legal Categories” (1993) 6:2 Canadian JL and Jur 343 at 353-54. Taking a broader perspective, Joseph Singer seeks to explore the "tensions and paradoxes intrinsic to property rights" in order to counter the "individualist turn" that the author recognizes as prolific: Joseph William Singer, Entitlement: The Paradoxes of Property (New Haven: Yale University Press, 2000) at 17. Singer describes the property system as being premised on the "[f]ull control by an owner" (ibid at 4). 
In all of these respects, the judgment diverges from the other few instances — all lowerlevel judgments - that have declined to equate animals to inanimate forms of property, but nonetheless affirmed a species hierarchy in which animals are inferior to humans. ${ }^{164}$ More importantly, it is entirely different from the main premise that animated the majority ruling of Justice Lamer of the Quebec Court of Appeal, as he then was, in Ménard, the leading case on anti-cruelty offences. ${ }^{165}$ Although this case involved an offence under the anti-cruelty provisions of the Criminal Code (as they then were), ${ }^{166}$ the structure of the federal legislation in Ménard and the provincial anti-cruelty legislation in Alberta at issue in Reece, are extremely similar: both subordinate animal interests to those of legal persons and calibrate "unnecessary suffering” (at issue in Ménard) and “adequate shelter” and "space” (at issue in Reece) according to cultural norms and relevant industry standards about acceptable animal use. ${ }^{167}$ It is thus instructive to compare the two provincial appellate court cases to illuminate how the dissent in Reece pushes the boundaries of welfarist legislation forward in a non-anthropocentric manner.

To begin, contrast Justice Lamer's words below with the passage of Chief Justice Fraser above:

Within the hierarchy of our planet the animal occupies a place which, if it does not give rights to the animal, at least prompts us, being animals who claim to be rational beings, to impose on ourselves behaviour which will reflect in our relations with them those virtues we seek to promote in our relations among humans. On the other hand, the animal is inferior to man, and takes its place within a hierarchy which is the hierarchy of the animals, and above all is a part of nature with all its "racial and natural" selections. ${ }^{168}$

Similar to Chief Justice Fraser, Justice Lamer emphasizes that we have duties to animals. Yet, his analysis draws on the traditional Kantian reasoning justifying anti-cruelty statutes — that we need to be kind to animals in order to inculcate kindness in ourselves. ${ }^{169}$ Unlike Chief Justice Fraser, Justice Lamer does not suggest that the anthropocentrism of this view is in any way problematic. Instead, he reinforces and promotes an anthropocentric (and

See Ringler, supra note 126; Munroe, supra note 126.

Ménard, supra note 21. This case has been followed explicitly only three times, but was mentioned 18 times since it was written. For other discussions that place Ménard as a leading case in Canadian anticruelty jurisprudence and contextualize the significance of this, see e.g. Christina G Skibinsky, "Changes in Store for the Livestock Industry? Canada's Recurring Proposed Animal Cruelty Amendments” (2005) 68:1 Sask L R 173 at 210; Elaine L Hughes \& Christiane Meyer, "Animal Welfare Law in Canada and Europe” (2000) 6 Animal L 23 at 58.

166 Criminal Code, RSC 1970, c C-34, s 402(1)(a) (now s 445.1(1)).

167 Consider the wording of each. The criminal anti-cruelty provision at issue in Ménard reads: "Every one commits an offence who wilfully causes or, being the owner, wilfully permits to be caused unnecessary pain, suffering or injury to an animal or bird" (the provision is still the same in the current code) (ibid). The provincial statute at issue in Reece, the Animal Protection Act, reads in part: "For the purposes of this Act, an animal is in distress if it is deprived of adequate shelter, ventilation, space, food, water or veterinary care or reasonable protection from injurious heat or cold"(supra note 56, s 1(2)). Note the similarly ambiguous content of both provisions: at first glance they appear to disallow any person to cause or allow the suffering of a nonhuman, but in effect they both rely on the judgment of humans in deciding what constitutes suffering.

$168 \quad$ Ménard, supra note 21 at 464.

169 For further discussion on Kant's justification for the state's prohibition of cruelty toward animals - that fostering kindness to animals will make us kinder to other humans - and its continued influence in the creation of modern anti-cruelty statutes, see for example Luis E Chiesa, "Why is it a Crime to Stomp on a Goldfish? — Harm, Victimhood and the Structure of Anti-Cruelty Offenses” (2008) 78:1 Miss LJ 1 at 31; Pamela D Frasch, “Addressing Animal Abuse: The Complementary Roles of Religion, Secular Ethics, and the Law" (2000) 8:3 Society \& Animals 331 at 334; Steven White, "Legislating for Animal Welfare: Making the Interests of Animals Count” (2003) 28:6 Alt LJ 277 at 278. 
racialized) hierarchy. Justice Lamer elaborates on his reasoning in this regard with the following passage from Ménard:

\begin{abstract}
The animal is subordinate to nature and to man. It will often be in the interests of man to kill and mutilate wild or domestic animals, to subjugate them and, to this end, to tame them with all the painful consequences this may entail for them and, if they are too old, or too numerous, or abandoned, to kill them. This is why, in setting standards for the behaviour of men towards animals, we have taken into account our privileged position in nature and have been obliged to take into account at the outset the purpose sought. ${ }^{170}$
\end{abstract}

Again, Justice Lamer takes as a given the anthropocentric hierarchy and presents it as a natural truth. He then uses this "truth" to explain why the instrumental and painful treatment of animals is warranted and is an appropriate constraint to any standards that anti-cruelty statutes set. The maintenance of human privilege and use of animals is cast as a valid purpose through which to interpret the anti-cruelty provisions before him in the case. The Quebec Court of Appeal judgment references long-standing Judeo-Christian religious and Western cultural influences without self-reflection as to whether such norms are outdated and should continue to influence the law. ${ }^{171}$ In contrast, the Alberta Court of Appeal dissent acknowledges how wider cultural thinking about animals has shaped the law and uses this dynamic to suggest that the law should evolve to keep pace with such thinking. ${ }^{172}$

We can see that Justice Lamer's departure point is one of validating human purposes, anthropocentric privilege, and animal subordination in contextualizing what counts as “cruelty.” The traditional common law thinking about animals is affirmed. This diverges markedly from Chief Justice Fraser's emphasis on stewardship and responsibilities to other beings who share our space and to the Earth, as well as her overall orientation that the law should be ready to move forward when it is dissonant with changing social values. Her judicial orientation and departure point clearly signal a more sophisticated and animal-centric judicial consciousness than what has existed previously in the jurisprudence. ${ }^{173}$

Ménard, supra note 21 at 464.

171 Ibid ("[the relevant legislation] reveals a legislative policy which seeks to recognize the protection of animals in accordance with the place which is theirs in the hierarchy of our 'world' and the responsibilities that we impose on ourselves as their 'masters'”). In this regard, the Criminal Code offence is not unique. Kyle Ash points out the cultural and religious underpinnings of animal welfare laws in general and questions their role in the cultivation of international laws pertaining to animals: Kyle Ash, "International Animal Rights: Speciesism and Exclusionary Human Dignity" (2005) 11 Animal L 195 at 197. Shannon Doheny analyzes a US Supreme Court case, making visible the Christian values which had been normalized in anti-cruelty legislation and which influenced the judgment of the practice of Santeria and animal sacrifice: Shannon L Doheny, "Free Exercise Does Not Protect Animal Sacrifice: The Misconception of Church of Lukumi Babalu Aye v. City of Hialeah and Constitutional Solutions for Stopping Animal Sacrifice" (2006) 2 Animal L 121 at 134. Rather than a religious approach, Dinesh Wadiwel takes a cultural approach, looking at the influence of Western philosophers on animal welfare laws: Dinesh Wadiwel, "Three Fragments from a Biopolitical History of Animals: Questions of Body, Soul, and the Body Politic in Homer, Plato, and Aristotle” (2008) 6:1 Journal for Critical Animal Studies 17 at 17.

172 Reece, supra note 7 at para 129: "One of the most important attributes of the common law remains its capacity for change in response to contemporary social norms and community values."

173 A case that also challenges the conventional species binary, but does not engage in a robust discussion of animals' interests as the Reece dissent does, is Harvard College v Canada, 2002 SCC 76, [2002] 4 SCR 45. Addressing the question at issue, the patenting of a genetically modified mouse, Justice Bastarache acknowledges the weakening of the human-animal binary: "The patenting of body parts raises yet another issue: the increasingly blurred line between human beings and other higher life forms. In the new field of xenotransplantation, human genes are introduced into mammals such as pigs to make the animals' organs more acceptable to the human body for the purposes of organ transplantation" (ibid at para 180). Despite troubling the boundary between human and nonhuman, Justice Bastarache's decision does not engage with the practicalities of animal exploitation which must be challenged if this 
The Chief Justice also increases the potential of welfarist legislation in two other significant ways. First, the dissent contests the influence that industry standards typically enjoy in judicial determinations of what is "necessary" to do to an animal and what is not. Recall the Ménard case from above. There, the shelter operator was convicted of the cruelty offence since his method of euthanizing animals fell below the method his competitors used. ${ }^{174}$ Ménard set a firm and leading precedent for measuring cruelty according to economic norms such that behaviour that met industry standards is held to be acceptable. ${ }^{175}$ Indeed, as noted above, some anti-cruelty statutes even explicitly include such an exception or defence to the offence in their text. ${ }^{176}$ The Reece dissent challenges this equivalence. Chief Justice Fraser states that although they are relevant, industry standards are not determinative of what qualifies as “adequate shelter" or "space” under the Alberta statute. ${ }^{177}$

The second manner in which Chief Justice Fraser expands the potential of welfarist legislation is through linking her discussion of animal vulnerability to human power under the property model to how she reads the purpose of the welfarist statute. She interprets the two statutes that make up Alberta's animal welfare laws - the Act and the Wildlife Act as well as their subordinate legislation — as "designed to protect a vulnerable group, animals, by establishing certain minimum standards that apply to their treatment." ${ }^{178}$ Reasoning that "vulnerability" as a state of being is embedded in the legislation alters the traditional welfarist understanding of this type of legislation with a more animal-centered reading, one that bestows the statute with animal rights purposes critical of human power over animals under the property model.

Of course, from an anti-exploitation perspective, it would be preferable not to have to filter an abolitionist purpose through a welfarist statute, as that method will invariably dilute the abolitionist viewpoint. Further, it may be argued, as Francione has, that welfarist laws impede the development of anything more substantial for animals since they mislead the public into believing that the law sufficiently addresses animal suffering. ${ }^{179}$ Recalling

binary is to be dissolved. There is no discussion of the debate in animal advocacy between rights and welfare, and the rhetoric is still predominantly anthropocentric. The similarity perceived between "higher life forms" and humans is a major part of the foundation of the decision: "The distinction between lower and higher life forms ... is nonetheless defensible on the basis of common sense differences between the two.... If the line between lower and higher life forms is indefensible and arbitrary, so too is the line between human beings and other higher life forms" (ibid at para 199). This argumentation maintains the human subject as the point of reference, comparing other life forms in relation. Ménard, supra note 21 at paras 59-60.

Other cases where the ruling is based on a comparison between the practice adopted by the accused and accepted industry practices are: $R v$ McGuire (1983), 32 CR (3d) 381 (Ont Co Ct); $R v$ Randell (1989), 96 AR 237 (Prov Ct); Cunningham, supra note 21.

See supra note 30.

Reece, supra note 7 at paras 119-20. The content of the guidelines, as summarized earlier in the judgment, is worth recalling here. First, the GASZA, supra note 73 applies to all zoos, including the Valley Zoo. The sections which are pertinent, to Chief Justice Fraser, state that all animals kept in zoos must be provided with adequate food and water, must be allowed to live with other animals of the same species, must be kept from suffering due to weather, and must be provided with veterinary care. These are all significant points because they reflect the very issues that contribute to Lucy's poor health (Reece, ibid at paras 79-83). Additionally, the Chief Justice reads in the guidelines provided by the American Zoo and Aquarium Association which explicitly state the need of elephants to have the opportunity to socialize with other animals (ibid at paras 84-87).

Reece, ibid at para 72.

This is a central point of contention in the abolitionist/welfarist debate and is articulated in Francione \& Garner, supra note 110 at 26. Garner opposes Francione's argument that welfare initiatives impede significant change for animals, advocating instead for a framework of "animal protectionism" (ibid at 104). Favre, who cultivates a different legal theory for the improved legal status of animals, similarly disagrees with Francione's reading of the effects of welfare initiatives, see generally, David Favre, 
Francione's important critique that the overwhelming majority of welfarist legislation simply makes exploitation more efficient, one may classify Chief Justice Fraser's insistence on better shelter and space than what industry standards currently provide with having this effect. From this perspective, the dissent in Reece works against animals' larger interests since it validates a regulatory scheme that permits and justifies animal captivity and their continued property status.

Addressing the entire "welfare-abolition" debate among animal scholars is not possible here, and would in any case quickly concede that Francione's and others' skepticism toward welfarist legislation highlights the limits of animal welfare laws in achieving any substantive level of animal protection. It would have been useful to receive the Chief Justice's views about this debate and know which level of critique of the current welfarist system she would advance. By refraining from endorsing the abolitionist critique, the judgment's overall challenge to law's anthropocentrism is compromised. Nevertheless, the dissent's interpretive move in reading the welfarist legislation through a non-anthropocentric lens pushes welfarist legislation beyond its comfort zone and initiates a judicial discourse of vulnerability that is now available to be harnessed to propel possible future abolitionist litigation.

Moreover, despite her engagement with welfarist legislation, the practical impact of Chief Justice Fraser's willingness to apply a more liberal and generous reading of anti-cruelty statutes than that which currently exists must be noted. Had it carried the day, the ruling would have had the potential for an abolitionist endpoint for Lucy. The dissent would have permitted the appellants to go to trial to show a violation of the welfare legislation in the hope of obtaining the remedy of a declaratory judgment. It would thereby allow a novel action in Canada. If successful, this judgment, in turn, could have sustained the remedy of transferring Lucy to live out her life in a sanctuary where she would avoid instrumental treatment. ${ }^{180}$ Sanctuaries, of course, also pose concerns when considering the interest of wild animals. As Lori Gruen notes in her thoughtful discussion of “dilemmas of captivity,” even properly run sanctuaries that provide the highest possible standard of care for animals and try their best to respect what Gruen calls the "wild dignity" 181 inherent to wild animals, frustrate some animal interests, notably the ability to mate and live without containment and beyond human-imposed restrictions. ${ }^{182}$ Yet, the Tennessee Elephant Sanctuary provides a better outcome than the Edmonton Zoo. Lucy would have finally been in an environment where her present and future needs and interests were put first and where she was not a commercial attraction valued for the revenue she generated.

“Living Property: A New Status for Animals Within the Legal System” (2010) 93:3 Marq L Rev 1021. The Appellants had secured residence for Lucy at the Elephant Sanctuary in Tennessee. Lucy would retain her legal status of property at the Tennessee sanctuary. But using Francione's metrics to evaluate whether a particular reform effort is abolitionist, the transfer would qualify. That is because Lucy would no longer be used for instrumental use, but cared for in a way to maximize her well being. The Sanctuary's mission statement indicates its non-instrumental vision of animals: "The Elephant Sanctuary exists for two reasons: To provide a haven for old, sick or needy elephants in a setting of green pastures, dense forests, spring-fed ponds and heated barns for cold winter nights; [and] To provide education about the crisis facing these social, sensitive, passionately intense, playful, complex, exceedingly intelligent and endangered creatures” (see “Our Mission,” online: the Elephant Sanctuary <http://www. elephants.com/ mission.php>). 


\section{F. SUMMARY}

As outlined here, the dissent contains considerable shortcomings. The first is the extent to which the cultural status of elephants and the many "human" capacities they exhibit inform Chief Justice Fraser's reasoning. Animals who are not held in high cultural esteem or do not resemble humans in form or behaviour may not have engendered similar reasoning. Moreover, in emphasizing Lucy's abilities to communicate, socialize, and in other ways behave as humans do, it may also be observed that the humanist reasoning implicitly casts an unfavourable light on other nonhumans who do not share these qualities. The second concern with the dissent stems from the implied acceptance of zoos as human institutions justified in keeping animals captive due to the judgment's willingness to work within the confines of Alberta's welfarist and thus property-reinforcing legislation.

Although both concerns present substantial objections to the Chief Justice's decision, they might be better characterized as points of departure for future decisions, rather than failures of this one. Given the near absence of any precedent upon which Chief Justice Fraser could base her decision, these limitations should not take away from the remarkable nature of the dissent in validating animal law as a field, elevating its subject matter to rule of law stature, and recognizing the vulnerability and subjectivity of animals. The innovative and animalcentric ways in which Chief Justice Fraser interprets the welfarist legislation must also be acknowledged. Her decision, in its rejection of an anthropocentric worldview, is categorically different from the leading Canadian decision on anti-cruelty laws. Moreover, she interprets the specific requirements of the Alberta statute in a fashion that challenges, rather than defers to, industry norms and emphasizes animal vulnerability. Both moves inject more legal attention to Lucy's interests than an interpretation of welfare statutes would normally afford; she is valued as a being in her own right rather than for her instrumental value to her owners.

\section{ConCLUSION}

Law is an anthropocentric institution. It has cemented a property status for animals where even the interests of those animals who are sentient and relational beings receive minimal attention. Statutes that purport to protect animals are limited in their effect since they are founded on and interpreted through anthropocentric assumptions about animal inferiority and reside in an overall legal framework that subordinates animals through their property classification. Doctrines against animal cruelty are mediated through anthropocentric reasoning of what constitutes "unnecessary suffering” such that most human practices involving animals are never even subject to anti-cruelty consideration. A full spectrum of non-life human interests thus routinely trumps the interests animals have in continuing their lives. It is primarily the gratuitous suffering of animals - unconnected to any human economic or culturally accepted purpose — that attracts the attention of anti-cruelty statutes. While some recent companion animal cases in private law arenas have recognized animals' value as more than purely economic, the companion animal focus for these initiatives is telling. Motivated as they are by the bonds that humans have with their companion animals, these recent private law changes aren't really a marked departure from legislated animal welfare in that they do not question the anthropocentric character of the law. 
That is precisely why Chief Justice Fraser's dissent in Reece is remarkable. To an extent not approximated before in a Canadian legal judgment, Chief Justice Fraser (1) assigns the issue of animal welfare with constitutional stature by representing Lucy's plight as a rule of law matter; (2) legitimates animal law as a serious area of scholarly concern and debate, noting the various philosophical positions that dominate the field, including the abolitionist ("no property") position, and referencing the leading academic literature discussing the doctrine; and (3) represents animals as beings made vulnerable by their property status whose lives hold value independent of their usefulness to humans. By connecting animal protection to the rule of law, seriously discussing the animal rights critique of the current legal status of animals, and emphasizing the vulnerability that ownership occasions for animals, the decision recognizes animals as worthy legal subjects. It further aligns with animal-centric purposes by impugning the normativity of anthropocentrism and associating the issue of how animals should be treated with human claims for justice.

Given these dimensions, the dissent is an outlier in the traditional anthropocentric landscape for animals. It resists the standard legal instrumentalist view of animals and even offers a new tool to those seeking to challenge Canadian judicial and legislative treatment of animals. As well, contrary to the majority judgment that declines to broaden the focus of the case from a purely procedural question, the dissent keeps Lucy as the focus. In seriously attending to the vulnerability of animals, including the plight of Lucy as an individual and not simply evaluating her treatment through industry standards as is the norm in interpretation of anti-cruelty laws, Chief Justice Fraser steers the interpretation of anti-cruelty doctrines toward a more promising direction for animals.

The Reece dissent thus constitutes an unprecedented moment for nonhuman animals in Canada in opposing law's typical Othering of animals. It is the type of high-level dissent that has the potential to herald changes in the common law even absent legislative intervention. Notably, it could plausibly anchor a line of reasoning that disrupts the precedent set by Ménard that accepts a rigid species hierarchy as an appropriate basis to interpret anti-cruelty statutes. Of course, as a dissent, the judgment does not alter the law for animals and leave to appeal the decision to the Supreme Court of Canada has been denied. Yet, as an appellate level decision authored by a Chief Justice, the decision's articulation of the need for a legal shift in terms of how the law should respond to animals is not easily ignored. With her judgment, Chief Justice Fraser institutes an opening for non-anthropocentric jurisprudence in Canada. 